\title{
Relational Database for the Geology of the Northern Rocky Mountains-Idaho, Montana, and Washington
}

Prepared in cooperation with the Idaho Geological Survey and the Montana Bureau of Mines and Geology

Data Series 371 
Inside Front Cover

This page left blank intentionally. 


\section{Relational Database for the Geology of the Northern Rocky Mountains-Idaho, Montana, and Washington}

By J. Douglas Causey, Michael L. Zientek, Arthur A. Bookstrom, Thomas P. Frost, Karl V. Evans, Anna B. Wilson, Bradley S. Van Gosen, David E. Boleneus, and Rebecca A. Pitts

Prepared in cooperation with the Idaho Geological Survey and the Montana Bureau of Mines and Geology

Data Series 371 


\section{U.S. Department of the Interior DIRK KEMPTHORNE, Secretary}

\section{U.S. Geological Survey Mark D. Myers, Director}

\section{U.S. Geological Survey, Reston, Virginia: 2008}

This report and any updates to it are available online at:

http://pubs.usgs.gov/ds/371/

For product and ordering information:

World Wide Web: http://www.usgs.gov/pubprod

Telephone: 1-888-ASK-USGS (1-888-275-8747)

For more information on the USGS - the Federal source for science about the Earth, its natural and living resources, natural hazards, and the environment:

World Wide Web: http://www.usgs.gov

Telephone: 1-888-ASK-USGS (1-888-275-8747)

Any use of trade, product, or firm names is for descriptive purposes only and does not imply endorsement by the U.S. Government.

Although this report is in the public domain, permission must be secured from the individual copyright owners to reproduce any copyrighted material contained within this report.

Suggested citation:

Causey, J.D., Zientek, M.L., Bookstrom, A.A., Frost, T.P., Evans, K.V., Wilson, A.B., Van Gosen, B.S., Boleneus, D.E., and Pitts, R.A., 2008, Relational database for the geology of the northern Rocky Mountains; Idaho, Montana, and Washington: U.S. Geological Survey Data Series 371, 37 p. and database [http://pubs.usgs.gov/ds/371/].

Cataloging-in-publication data are on file with the Library of Congress (http://www.loc.gov/).

Produced in the Western Region, Menlo Park, California

Manuscript approved for publication, August 27, 2008

Text edited by Tracey L. Suzuki

Layout by Judy Weathers 


\section{Contents}

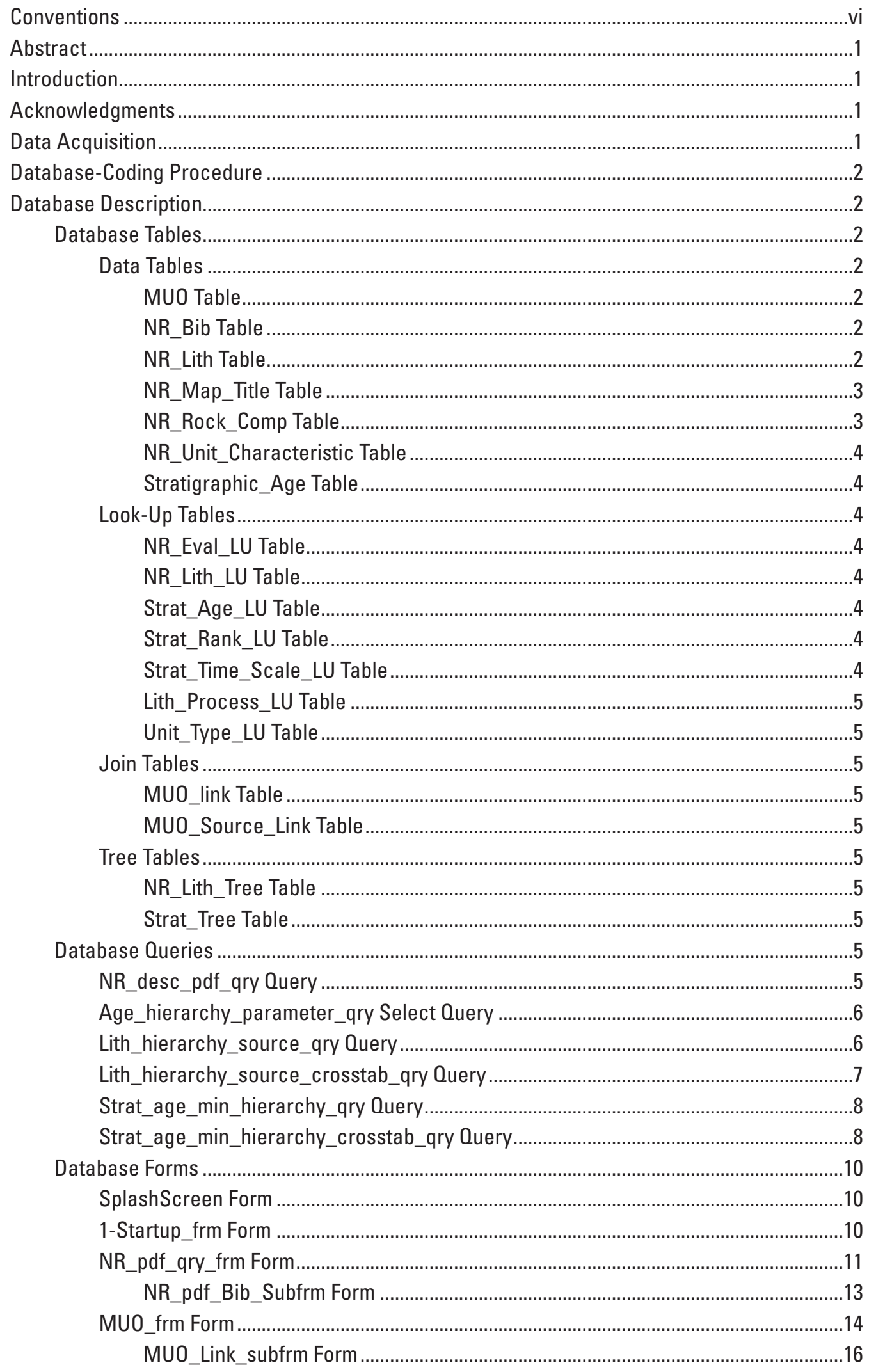




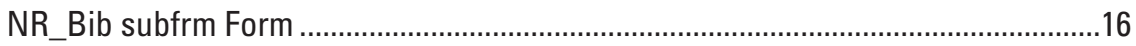

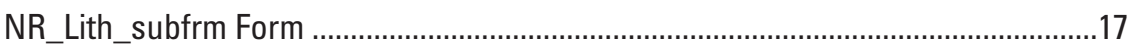

NR_Rock_Comp_subfrm Form ..........................................................................17

NR_Unit_Characteristic_subfrm Form ................................................................18

Stratigraphic_Age_subfrm Form........................................................................

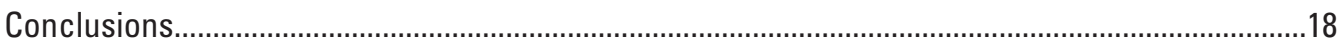

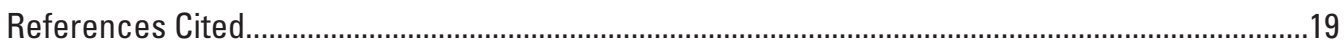

\section{Figures}

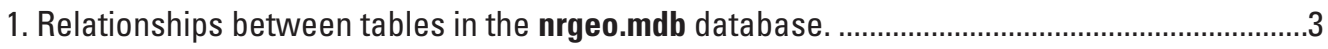

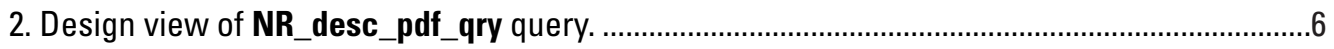

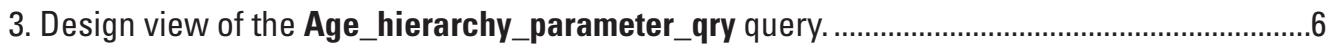

4. Design view of Lith_hierarchy_source_qry query......................................................................

5. Design view of Lith_hierarchy_source_crosstab_qry query..................................................

6. Example of output from the Lith_hierarchy_source_crosstab_qry query...................................

7. Design view of the Strat_age_min_hierarchy_qry query..........................................................

8. Design of the Strat_age_min_hierarchy_crosstab_qry query....................................................

9. Query Properties window for the "Column Heading" entry in the "Crosstab:" row of the design view of the Strat_age_min_hierarchy_crosstab_qry query............................9

10. Example of output from the Strat_age_min_hierarchy_crosstab_qry query...............................10

11. Forms and their description in nrgeo.mdb database............................................................11

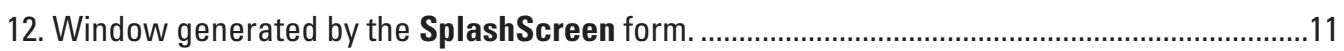

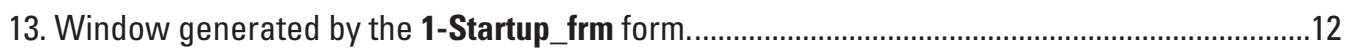

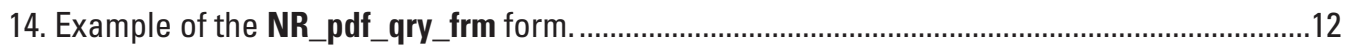

15. Properties for Detail section of Design view of the NR_pdf_qry_frm form..............................13

16. Example of printed output for MU_id = 2098 demonstrating how the "Can Grow" property, when set to "Yes" for the "Description of Map Unit" text box, permits the entire

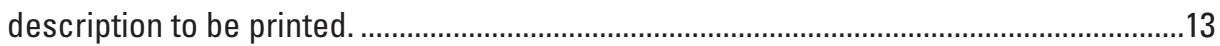

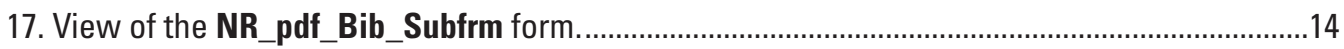

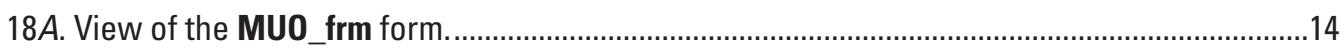

18B. View of layout for the Age-tabbed page in MUO_frm form. ................................................15

18C. View of layout for the Miscellaneous Properties-tabbed page in the MUO_frm form............15

18D. View of layout for the Rock Composition-tabbed page in the MUO_frm form..........................15

18E. View of layout entries for the References-tabbed page in the MUO_frm form.......................16

19. Properties for Text Box MU_id on the Data tab of the Design view

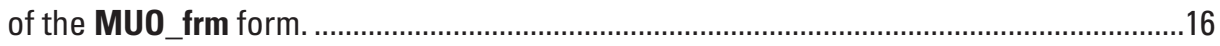

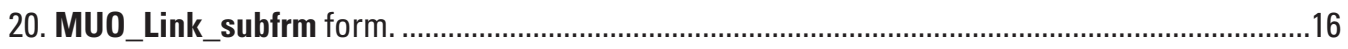

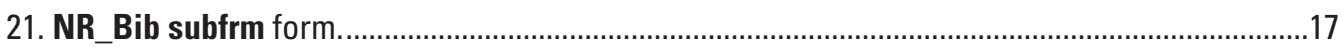

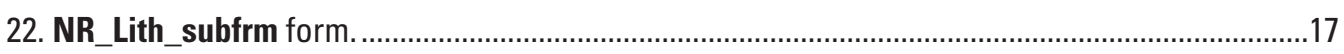

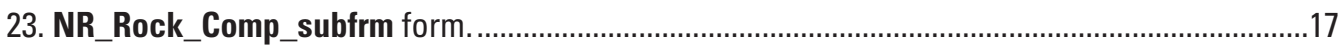

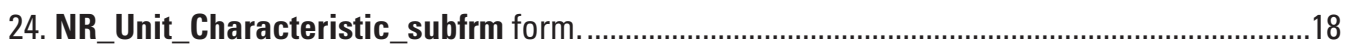

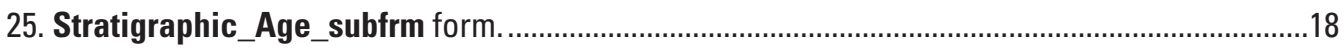


26. Dominant-lithology map of the northern Rocky Mountains

27. Geologic units in the northern Rocky Mountains described

by source authors as containing sulfide minerals.

28. Geologic units in the northern Rocky Mountains described

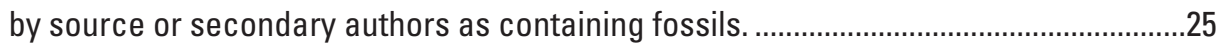

29. Stratigraphic-age map of the northern Rocky Mountains.

\section{Tables}

1. List of objects (tables, queries, and forms) in the nrgeo.mdb database. ................................28

2. MUO table design and summary.

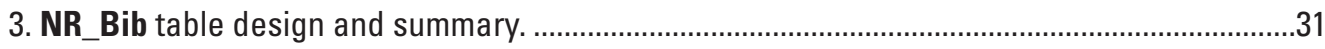

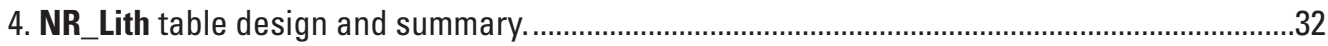

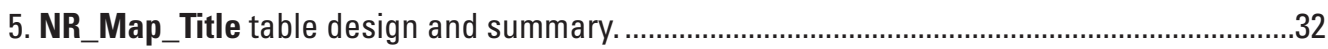

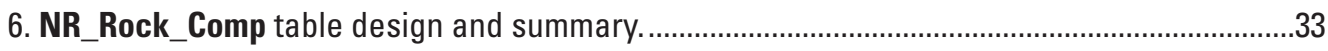

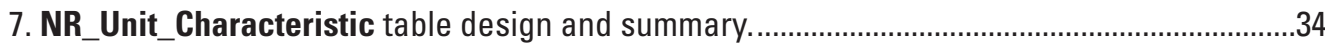

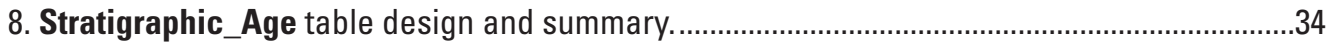

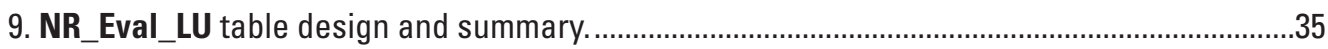

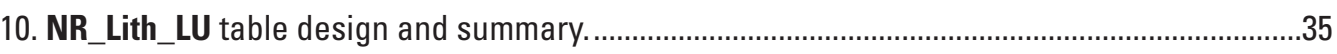

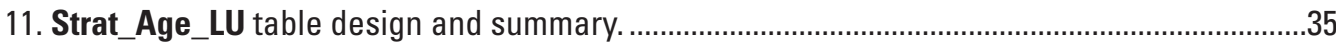

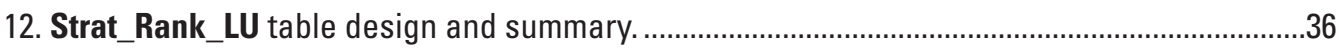

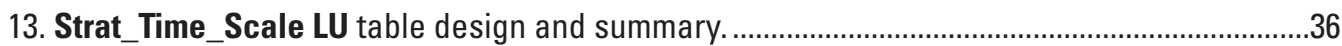

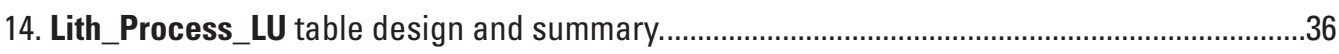

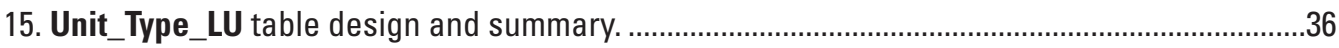

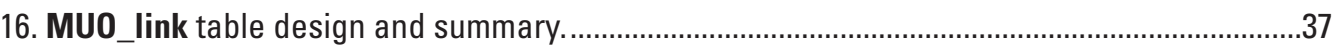

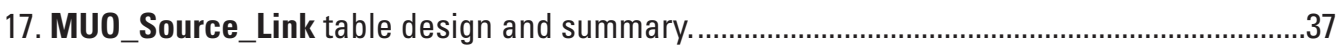

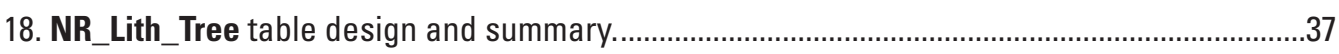

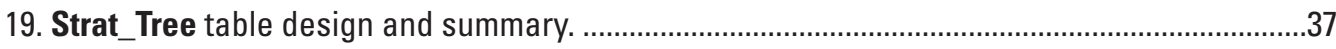




\section{Conventions}

Names of databases, tables, forms and queries are shown in Times font, boldface type. Field names (column headers) in tables are shown in italics.

To clarify which table is being discussed in relation to a particular field, the field name may be preceded by the table name and a period, and the whole term is shown only in italics (for example, MUO.MU_id for the MU_id field in the MUO table) 


\title{
Relational database for the geology of the Northern Rocky Mountains-Idaho, Montana, and Washington
}

\author{
By J. Douglas Causey, Michael L. Zientek, Arthur A. Bookstrom, Thomas P. Frost, Karl V. Evans, Anna B. \\ Wilson, Bradley S. Van Gosen, David E. Boleneus, and Rebecca A. Pitts
}

\section{Abstract}

A relational database was created to prepare and organize geologic map-unit and lithologic descriptions for input into a spatial database for the geology of the northern Rocky Mountains, a compilation of forty-three geologic maps for parts of Idaho, Montana, and Washington in U.S. Geological Survey Open File Report 2005-1235. Not all of the information was transferred to and incorporated in the spatial database due to physical file limitations. This report releases that part of the relational database that was completed for that earlier product. In addition to descriptive geologic information for the northern Rocky Mountains region, the relational database contains a substantial bibliography of geologic literature for the area.

The relational database nrgeo.mdb is available in Microsoft Access version 2000, a proprietary database program. The relational database contains data tables and other tables used to define terms, relationships between the data tables, and hierarchical relationships in the data; forms used to enter data; and queries used to extract data.

\section{Introduction}

The process of compiling geologic maps is complex and time consuming and producing a geologic-map compilation in a digital format is even more complicated. Databases designed to hold and display spatial information in a geographic information system (GIS) often cannot store lengthy descriptive text. Complex relationships between data stored in various tables cannot easily be shown in map products. This report describes a relational database of geologic map-unit descriptions, lithologic descriptions, and a bibliography that was designed to capture geologic-map information and provide that data to the nr_geo spatial database published in Zientek and others (2005). This report is not a user manual.

The nrgeo.mdb relational database contains descriptions for 3,465 geologic-map units from both original geologicmap sources and the resultant geologic-map compilation by Zientek and others (2005). This database exemplifies how converting existing published geologic-map data into a compilation where all geologic information is stored in a single relational database can be accomplished. Both the original geologic-map data and the data generated from the compilation are stored and related so that the user can identify the source material for the compilation. It is also possible to use this data in conjunction with GIS products that contain a field having the same identifier.

\section{Acknowledgments}

We would like to thank Reed Lewis of the Idaho Geological Survey (IGS) for his assistance in interpreting some of the published maps. Louden Stanford (IGS) provided map descriptions in digital format. Karen Porter, Dick Berg, and Ken Sandau of the Montana Bureau of Mines and Geology, provided digital files of geologic-map descriptions for several of the Montana 1:100,000-scale geologic maps. Ellen Burch, contractor, scanned-map unit descriptions from paper maps and documents and converted them to text by using optical character recognition software. Karen Lund, Mike O'Neil, and Greg Green of the U.S. Geological Survey (USGS) provided digital pre-publication data for the database. Boyan Brodarick of the Canadian Geological Survey, and Bruce Johnson and Gary Raines (USGS) provided input to the database design. Bruce Johnson provided an Access database containing tables following the DGMDM 4.3 design (Johnson and others, 1999). Dave Bedford, Ryan Stevens, and Jordan Hastings (USGS) provided Visual Basic programming that was utilized in some of the database coding.

Pamela Dunlap and Matt Granitto reviewed the report.

\section{Data Acquisition}

The process of acquiring and incorporating existing data into the nrgeo.mdb relational database was a multistage process. Data in a text format that could not be obtained digitally were acquired by using optical character recognition (OCR) 
software, which converts text from paper documents and maps to a digital format. The digital text data were then formatted for input into a spreadsheet program. The information for each map unit was parsed into various cells in a Microsoft Excel spreadsheet, and additional information was added to each record: a unique identification number for each record, an abbreviated source-map name, a source identification number, and the type of map object. These data were then imported from the spreadsheet into the MUO table of the nrgeo.mdb Access database. Map-unit descriptions acquired in Microsoft Access database format from the IGS were imported into the nrgeo.mdb database tables.

\section{Database-Coding Procedure}

After the raw data were incorporated into the database, Microsoft Access input forms were used to assist in standardizing terminology and to code additional fields with interpreted data. Where possible, the coder (evaluator) was a geologist who had been involved in creating the source map, or who had first-hand knowledge of the geology of the area.

Because the coders were not co-located, the database was replicated, and a copy was given each evaluator. Specific map units were assigned to each coder to prevent more than one person from working on the same records. Look-up tables were created and used as standards against which the data were checked for quality assurance. The database replicas were synchronized periodically with the master database. After the coding was completed, the data were reviewed for consistency and obvious errors were corrected.

\section{Database Description}

The nrgeo.mdb relational database contains data tables, as well as other components used to relate the data tables, to provide hierarchical structure, and to provide mechanisms for data entry and data query (table 1).

\section{Database Tables}

There are 19 tables in the nrgeo.mdb database (table 1; note that all tables are at the back of this report): 7 data tables, 7 look-up tables, 2 join tables, and 2 tree tables. Each individual table and its purpose is described in the following paragraphs. Relationships between the tables are shown in figure 1. Several look-up tables were designed to standardize input; they are used to produce outputs and serve as lists of valid values for some fields in the data tables. The join tables allow connections to be made between the data tables by defining relationships between particular fields. The tree tables are used to produce hierarchical simplifications of rock-type and stratigraphic-age terms.

Brief descriptions of the tables and definitions of the fields in the tables are also included in the digital files. (Tables and their descriptions are listed in the Database window; to view a list of fields and their definitions, highlight the table name and either click on the Design icon in the menu bar, or right-click on the table name and select Design View in the pop-up menu.)

\section{Data Tables}

\section{MUO Table}

The main data table, MUO (table 2), stores basic information about geologic-map units with records for both the regional-map units ( $M U \_i d$ greater than or equal to 10,000) compiled by Zientek and others (2005) and the original map units ( $M U \_i d$ between 1 and 4,977), as described on the forty-three source maps and databases. Map-unit descriptions (MU_desc field) for the regional-map units often are long and complex, because they were generated by concatenating descriptions from the source materials.

Two of the map-unit label fields, $M U_{-} l a b \_g a f$ and $M U_{-}$ lab_gaf_or, contain keyboard characters designated for use by the GeoAgeFullAlpha font set, a font set created by the U.S. Geological Survey to display special characters commonly used on geologic maps to indicate ages of rock units. (For example, *_ will display as $\mathbb{P} €$ when using the GeoAgeFullAlpha font set.) These special characters display as standard geologic-age symbols only in forms (for example, MUO_frm, NR_pdf_ qry_frm) that are opened by using computers on which the font set is installed.

\section{NR_Bib Table}

A bibliography of the geology of the northern Rocky Mountain region is stored in the NR_Bib table (table 3). All references cited on the original source maps and related documents used to generate the regional compilation (Zientek and others, 2005) are included in the NR_Bib table. The table design allows for queries and sorts by author, date, title, name of publication, and map scales.

The database contains many references that were acquired by scanning the reference lists from the source-map publications and from other sources related to the geology of the northern Rocky Mountain region. While not an exhaustive listing, the bibliography contains more references than those cited in Zientek and others (2005).

\section{NR_Lith Table}

The NR_Lith table (table 4) contains lithologic (rock composition) information about each geologic-map unit. The table mainly contains interpretations of lithology based on the map-unit descriptions from the source maps. Three fields (primary_lith, subordinate_lith, and incidental_lith) contain lithologic terms extracted from the original map-unit descriptions and differentiated based on linguistic interpretations. That is, a set of rules was developed to attempt to capture the mapper's intent. 
In order to populate the dom_lith field, the terms in the primary_lith field were used to select a representative dominant lithology term from the look-up table NR_Lith_LU, a master list of lithologic terminology.

Additional information in the NR_Lith table includes the geologic or morphologic form of the unit (unit_form), if known; yes/no entries to identify unit descriptions that contain economic information (econ_geol); evaluators (lith_eval) and their comments (lith_comment); and the rule used to parse the lithology terms into the various fields (lith_process).

Information in the dom_lith field was exported to the lname_dom and uname_dom fields in the NR_GEO.LITH and NR_GEO.UN tables of the NR_GEO spatial database (Zientek and others, 2005), respectively. Data in the primary lith field were exported to the name_majrl and name_majr2 fields in the NR_GEO.LITH table and the name_major field in the NR_GEO.UN table. Attributes in the subordinate_lith field were exported to the name_minor field in the NR_GEO. LITH and NR_GEO.UN tables, and information in the inci- dental lith field was exported to the name other field in the NR_GEO.LITH and NR_GEO.UN tables.

\section{NR_Map_Title Table}

The NR_Map_Title table (table 5) contains the map titles for maps that were used in the regional compilation by Zientek and others (2005) and is related to table MUO by the map_tile field. This table provides the source-map title and spatial database map-tile information on the form NR_pdf_qry_frm.

\section{NR_Rock_Comp Table}

Data from the NR_Rock_Comp table (table 6) was not included in the regional compilation by Zientek and others (2005). NR_Rock_Comp was populated by separating all the terms in the primary_lith, secondary_lith, and incidental_lith fields of the NR_Lith table into individual records and importing them to the rock_name field. Due to a lack of volume percentages of the various lithologies within each map-unit description in the source literature, a lithology rank

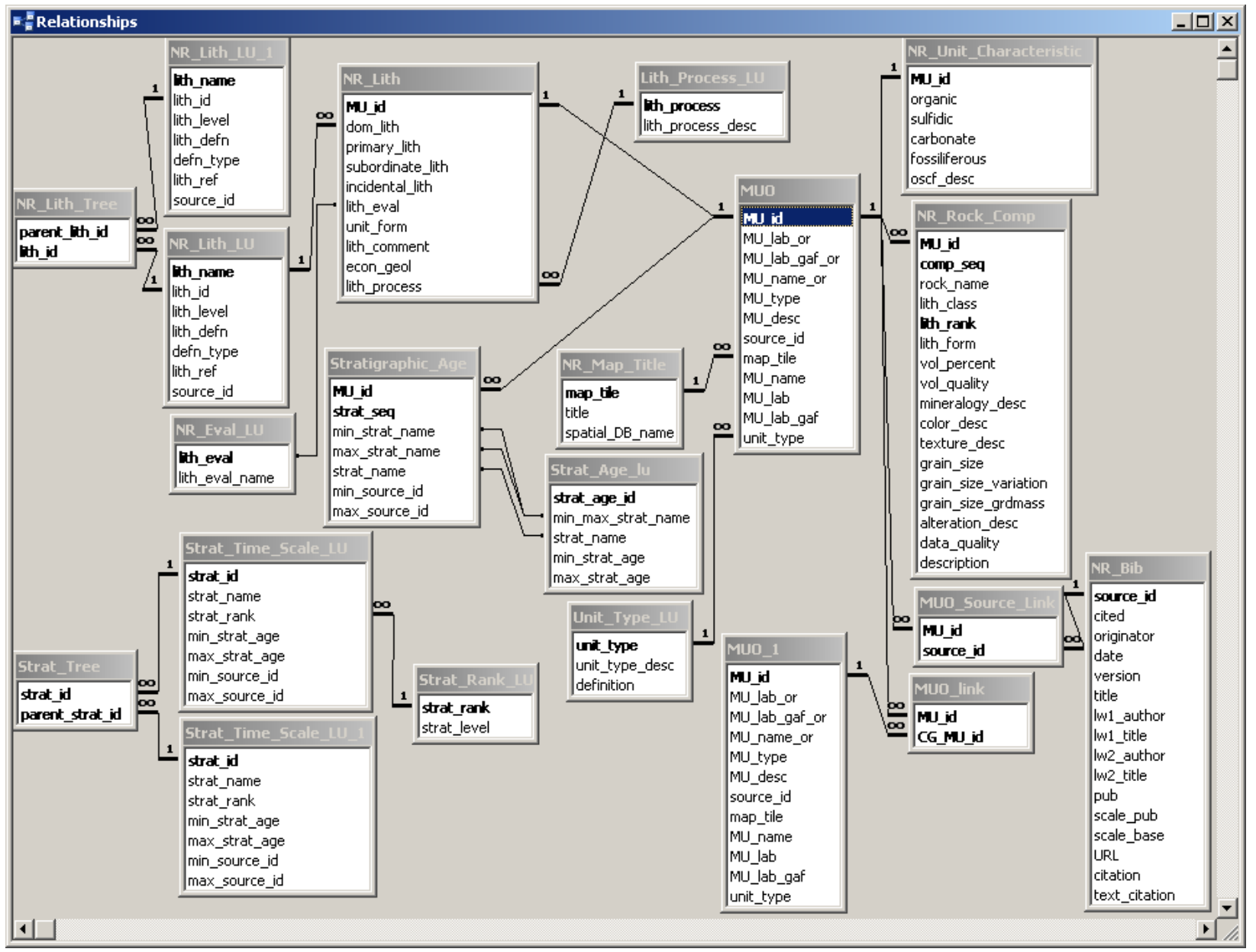

Figure 1. Relationships between tables in the nrgeo.mdb database. (Bold-faced text designates primary key fields. Infinity symbol indicates the "many" table in a many-to-one join.) 
(lith_rank) of 1, 2, or 3 was assigned depending on whether the data was derived from the primary_lith, secondary_lith, or incidental_lith field, respectively. In cases where the same rock type was listed in two or more of these fields, the rank was assigned according to the most important field (where primary_lith $>$ secondary_lith $>$ incidental_lith). For example, if both primary_lith $=$ sandstone and secondary_lith $=$ sandstone for the same map unit, then lith_rank $=1$.

Other than parsing rock terms into individual records, assigning a rank, and removing duplicates, no coding of other fields in this table was done. The other fields (table 6) are available for future attribution.

\section{NR_Unit_Characteristic Table}

The NR_Unit_Characteristic table (table 7) contains interpreted data. The table identifies rock units containing certain physio-chemical properties. Most of the field attributes are Boolean (yes/no) and indicate whether or not a particular property is present within the unit. A "yes" does not mean that that property is present throughout the unit, but that it is present in at least some of the rocks.

The binary fields provide a means to categorize map units based on factors such as: contains organic material, contains sulfides, contains carbonates, or contains macrofossils. These determinations are based almost entirely on the written descriptions provided by the map-unit sources. Some data were improved by examining secondary sources, but most of the determinations relied on primary-source map descriptions.

\section{Stratigraphic_Age Table}

The Stratigraphic_Age table (table 8) contains the stratigraphic ages of the rocks in the map units in the northern Rocky Mountains compilation (Zientek and others, 2005). The table contains both a minimum and a maximum age for each map unit, as well as a term that combines the minimum- and maximum-age terms and generalizes that term to a geologicperiod term. A higher-level term is used in the strat_name field if the period-age level is not possible. There are a few map units of unknown age.

\section{Look-Up Tables}

\section{NR_Eval_LU Table}

The look-up table NR_Eval_LU (table 9) contains a list of the names and initials of the people who evaluated and entered map-unit data into the database. This table was used to determine which initials to use for the people who coded the lithologic data (in attributing the lith_eval field of the NR_Lith table). It should be noted that the look-up table NR_Eval_LU was not used as a digital drop-down or pick list for automated data entry.

\section{NR_Lith_LU Table}

The look-up table NR_Lith_LU (table 10) is a list of lithology terms for use in populating the dom_lith field of the NR_Lith table. It also provides definitions and references for the lithologic terminology, as well as a value to indicate hierarchical level within this classification system.

Geologic terminology provides several ways to describe rocks. This descriptive terminology ranges from general field terms based on megascopic characteristics to terms based on microscopic, geochemical, genetic, physical, or some combination of these properties. Because the source material for the map compilation used rock terms generated and defined by several different classification schemes, the authors did their best to convert the terms to a single scheme that is composition-based. This was not always possible; the list of terms in the NR_Lith_LU table also contains terms that describe rock genesis (in addition to rock composition).

\section{Strat_Age_LU Table}

The look-up table Strat_Age_LU (table 11) contains geologic age terms used in the Strat_name field in the Stratigraphic_Age table. In order to provide a single age term for a map unit, terms were hyphenated for map units that spanned two or more age ranges. Hyphenated terms begin with the youngest term and end with the oldest (for example, Eocene-Late Cretaceous). The table also provides terms that are generalized to the geologic period or higher-level term (for example, Tertiary-Cretaceous). The table is not comprehensive of all possible terms; it only includes ages that were used on the maps compiled in Zientek and others (2005). The table does not contain undefined terms used by authors, such as late Paleozoic or middle Tertiary. Where used, these terms were recoded as 'Paleozoic' or 'Tertiary' when more detailed information did not exist.

This table can be used to create a list of map units in chronologic order by using the numerical fields min_strat_age and max_strat_age. A query ordered by "Sort ascending" on either of these fields will produce a list with the youngest unit at the top and ascending in age to the oldest unit at the bottom.

\section{Strat_Rank_LU Table}

The look-up table Strat_Rank_LU (table 12) is based on the North American Digital Geologic Data Model v. 4.3 (Johnson and others, 1999). The strat_level field is used to assign a hierarchical level to the stratigraphic-rank attributes (for example, eon, epoch, era, period) listed in the strat_rank field in the look-up table Strat_Time_Scale_LU.

\section{Strat_Time_Scale_LU Table}

The look-up table Strat_Time_Scale_LU (table 13) contains the geologic-age terms used in this database. Several published geologic time scales were examined for use of terminology and age ranges in this database: Haq and Van 
Eysinga (1998), Hansen (1991), Palmer (1998), Palmer and Geissman (1999), Remane (2003), and Wilson (2001). No one source contained all the names used in the source maps. Haq and Van Eysinga (1998) and Hansen (1991) presented the best combination of names and dates for stratigraphic ages, and these two sources were chosen to use for the time-scale.

The strat_rank field for the Precambrian age was coded as "eon" rather than the correct term "informal" to enable the user to create a hierarchical list of stratigraphic ages if relatively equivalent terms existed in one column (field).

The Strat_Time_Scale_LU table is used to code the min_strat_age and max_strat_age fields in the Stratigraphic Age table.

\section{Lith_Process_LU Table}

The look-up table Lith_Process_LU (table 14) provides descriptions of the parsing rules listed in the Lith_process field in the NR_Lith table. The assumptions and philosophy used to convert linguistics (inconsistently formatted text strings) to a categorical system (standardized) are described in Zientek and others (2005, appendix E).

\section{Unit_Type_LU Table}

The look-up table Unit_Type_LU (table 15) defines the codes used in the unit_type field of the MUO data table. The look-up table provides terms to classify the map units, based on their geologic unit name, into one of five categories: formal name, informal name, informal part of formal unit, not a geologic unit, unconsolidated unit.

\section{Join Tables}

\section{MUO_link Table}

The MUO_link table (table 16) is a special type of join table that provides a connection (defines a relationship) between the source-map units and the compiled regional-map units in the MUO data table. This self-joining or reflexive relationship makes it possible to generate and store records for the output units in the same table that contains records for the input units. The MUO_link table was used to ensure that unique $M U \_i d$ values were created for all of the output units and that all output units matched an existing set of input values.

\section{MUO_Source_Link Table}

The MUO_Source_Link table (table 17) is an intermediate table needed to provide one-to-many joins between the MUO and the NR_Bib tables. Without the MUO_Source_ Link table, the relationship between the two data tables would be many-to-many, and it would be impossible for the software to link records. This intermediary table sets up a one-to-manyto-one relationship: one MUO_id in the MUO table can be connected or joined to many MUO_id values in the MUO_Source
Link table which in turn can be joined by using the source_id to one value in the NR_Bib table (as shown in figure 1).

\section{Tree Tables}

\section{NR_Lith_Tree Table}

Because most lithologic terms are based on a hierarchical classification system, it is possible to generalize terms. The NR_Lith_Tree table (table 18) is a special table that was constructed to enable users of the database to generalize lithologic descriptions of map units. The table can be used to generalize lithology terms listed in the NR_Lith table to any of five levels. By using the crosstab query Lith_hierachy_source_crosstab_qry, a full hierarchical list of terms can be generated for most of the map units (exceptions include some units that are represented as linear features by Zientek and others, 2005).

\section{Strat_Tree Table}

Stratigraphic ages are based on a hierarchical classification system that makes it possible to generalize or group ages. The Strat_Tree table was constructed to enable users of the database to group the ages for individual map units. The Strat_Tree table (table 19) can be used to group ages of map units to any of three levels. By using a crosstab query in the database, the ages can be grouped to eon, era, or period. An example query (Strat_age_ min_hierarchy_crosstab_qry) is included in the database to group the map units by youngest (minimum) age.

\section{Database Queries}

There are six query routines in the database (table 1): two crosstab queries convert hierarchical data to a simple, tabular flat-file output format of rows and columns; two select queries provide the data to the crosstab queries; one select query supplies data for export to Adobe PDF; and one parameter query produces a generalized age list based on user input. Three of the queries can be invoked by the user in the initial start-up form. Two of the queries are called by the other queries.

\section{NR_desc_pdf_qry Query}

The NR_desc_pdf_qry query (fig. 2) provides descriptive map-unit data (from the MUO table) to the NR_pdf_ qry_frm form. The query provides a mechanism to display the name of each original map unit with the name and other descriptive information for the corresponding compiled unit in a simple tabular format and as a form. The query uses the oneto-many relationship of the MUO table with the MUO_link table to show the stratigraphic ages assigned to the Northern Rocky Mountain map units of Zientek and others (2005) with the $M U_{-} i d$ values in that report. The description field $\left(M U_{-}\right.$ desc) is a memo field and was not included in the published ESRI Arc coverage format because that format does not allow inclusion of memo-type data fields (long text strings). Thus, 
this query provides a mechanism to show lengthy descriptive data in a form that can be exported to PDF format.

\section{Age_hierarchy_parameter_qry Select Query}

The Age_hierarchy_parameter_qry query (fig. 3) is a parameter query. It allows the user to generalize units to a particular stratigraphic-age rank: eon, era, period, subperiod, or epoch. When this query is invoked, the user is asked to specify an age rank. The output lists (in the two far-right columns) the specific stratigraphic age (strat_name) and corresponding age rank (Strat_ Time_Scale_LU_1.strat_rank). Records for rock units that have only been assigned a higher-level age will not appear in the output for generalization requests for lower-level age ranks (for example, generalizing to period when the rock unit's age is not attributed any finer than era will not return records for those units).

Users need to be careful when interpreting the results of this query because rock units are assigned both a minimum and a maximum age in the database. The query is designed to return the youngest (minimum) age of each map unit. For about 80 percent of the units, it does not matter which age field is used since most units have the same minimum and maximum age; however, it does make a difference for the other 20 percent. The query can be modified to output the maximum age by removing the join between Stratigraphic Age.min_strat_name and Strat_Time_Scale_LU.strat_name and invoking a new join between Stratigraphic_Age.max_ strat_name and Strat_Time_Scale_LU.strat_name.

\section{Lith_hierarchy_source_qry Query}

The Lith_hierarchy_source_qry query (fig. 4) is an intermediate query used to create necessary relationships so that a hierarchical tree of rock types can be constructed. This query provides data to the crosstab query Lith_hierarchy_ source_crosstab_qry.

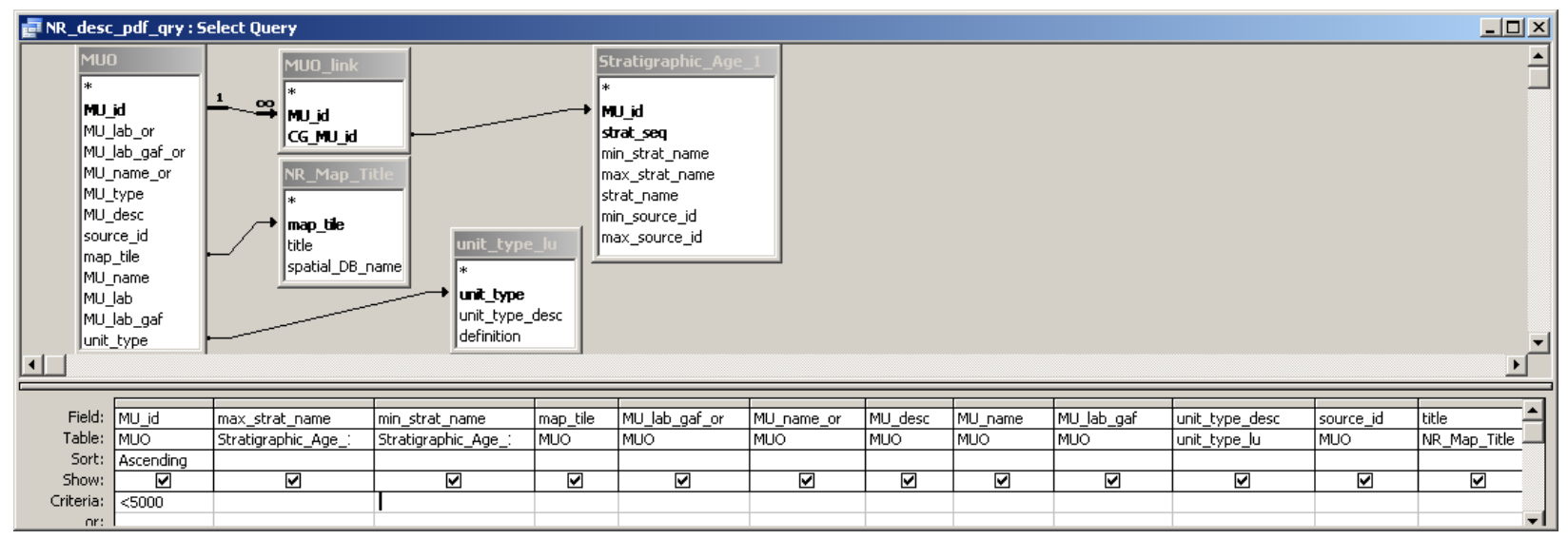

Figure 2. Design view of NR_desc_pdf_qry query.

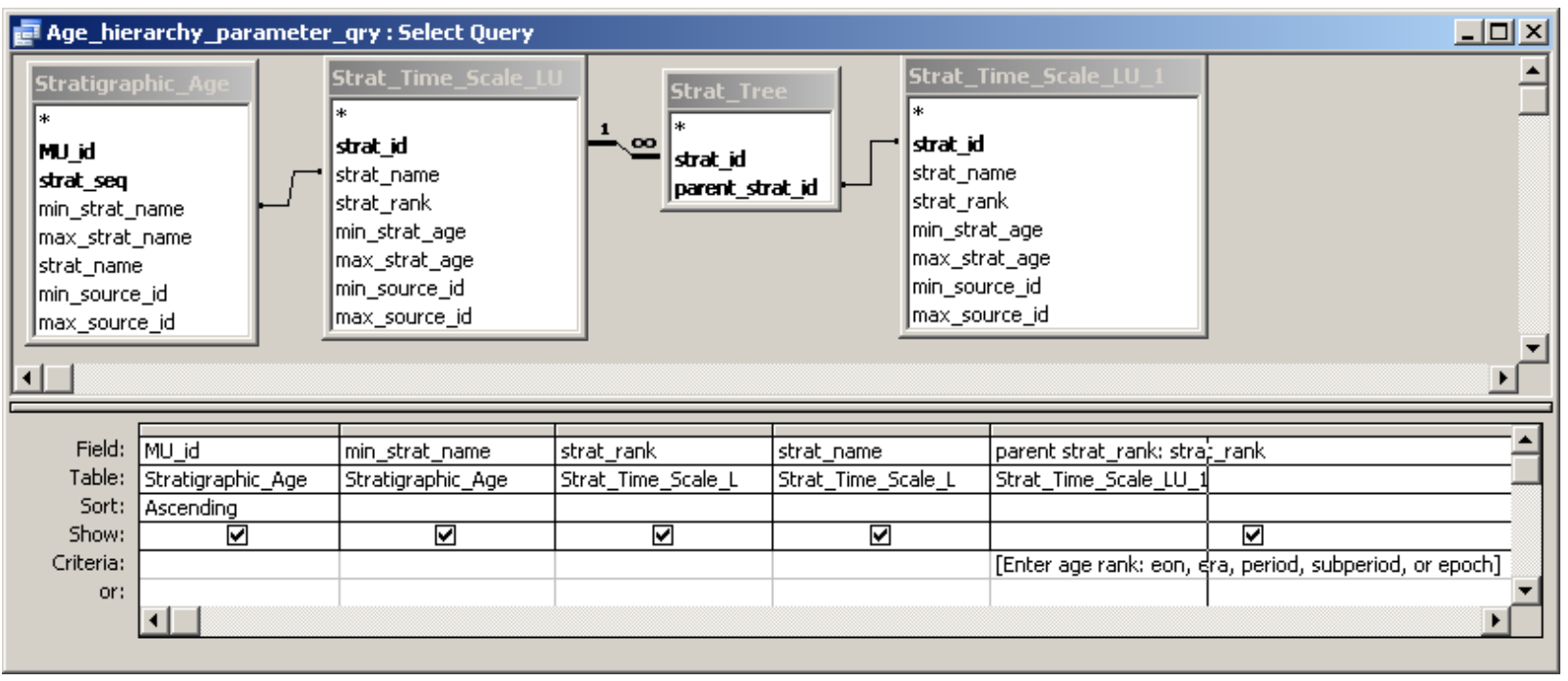

Figure 3. Design view of the Age_hierarchy_parameter_qry query. 


\section{Lith_hierarchy_source_crosstab_qry Query}

The Lith_hierarchy_source_crosstab_qry query (fig. 5) provides a tabular output listing generalized rock terms at each of five hierarchical levels (see columns labeled 1 through 5 in fig. 6) for the dominant lithology (dom_lith) attribute for each map unit. Rock terms listed in the 1 column (most general litho- logic name; corresponds to lith_level $=1$ in the $\mathbf{N R} \_$Lith_LU table) were used to populate the lname_l field in the $\mathbf{n r}$ _geo. lith table and uname_l in the nr_geo.un table in the $\mathbf{n r}$ _geo spatial database of Zientek and others (2005), and so on for columns 2 through 5 . Any changes in the rock type assigned to a map unit (dom_lith in the NR_Lith table) will be reflected immediately in the output from this query.

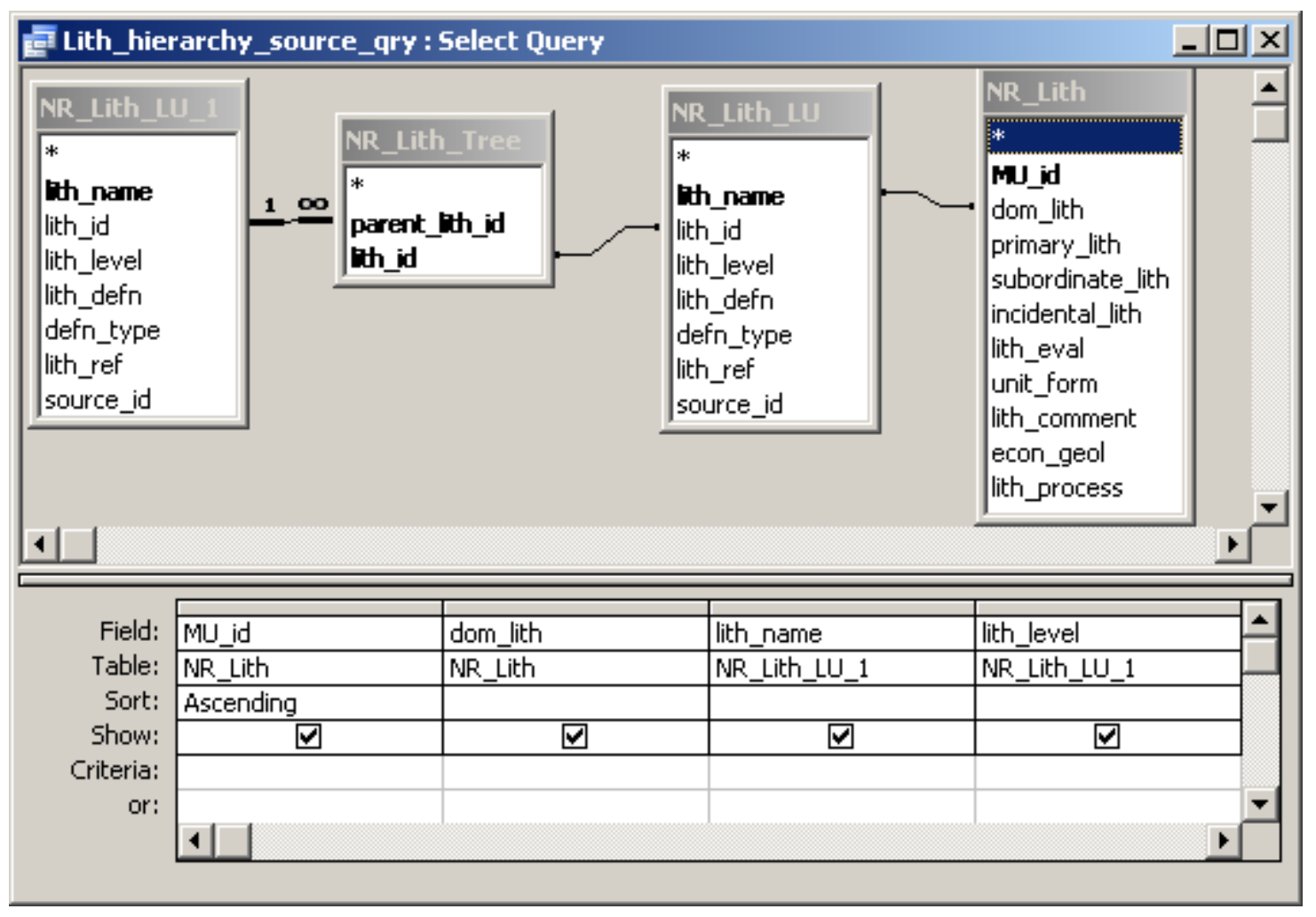

Figure 4. Design view of Lith_hierarchy_source_qry query.

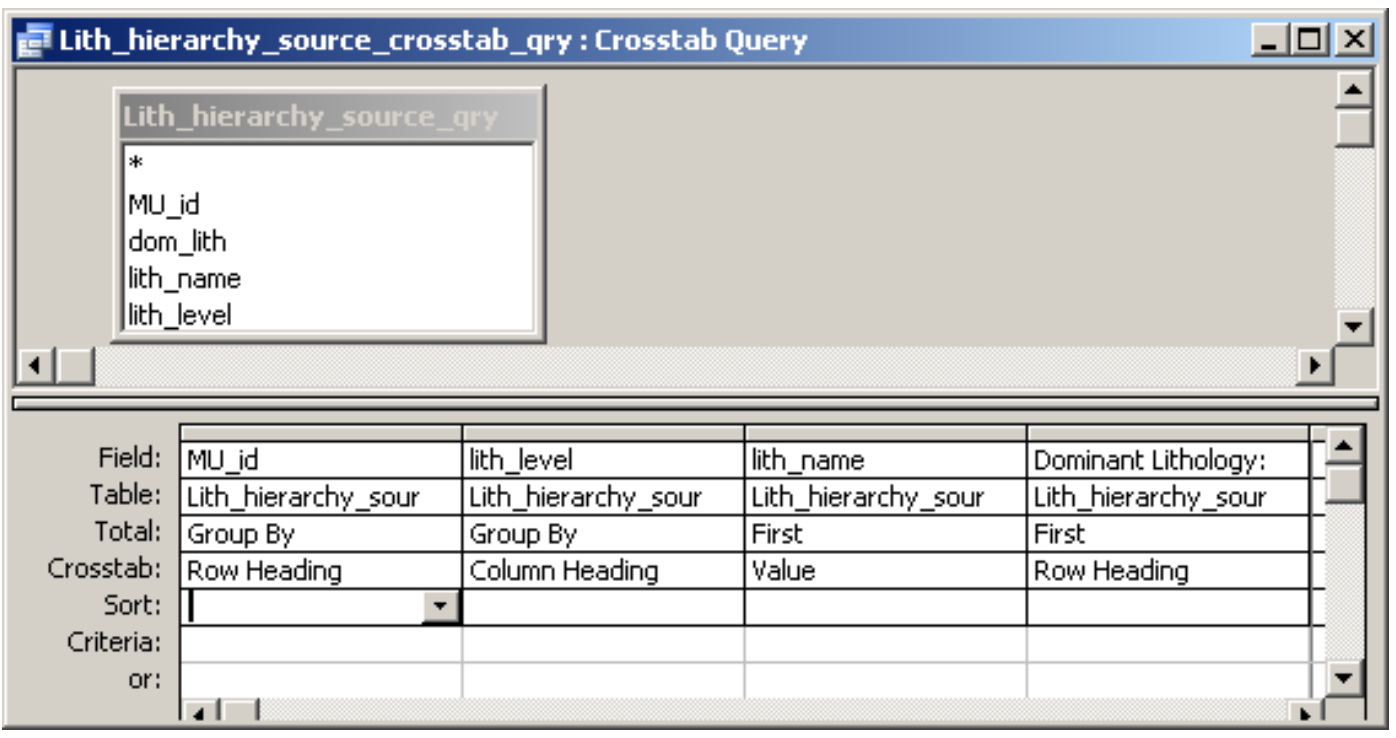

Figure 5. Design view of Lith_hierarchy_source_crosstab_qry query. 


\section{Strat_age_min_hierarchy_qry Query}

The Strat_age_min_hierarchy_qry query (fig. 7) is an intermediate query used to create necessary relationships so that a hierarchical tree of map-unit ages can be constructed. This query provides data to the crosstab query Strat_age_ min_hierarchy_crosstab_qry.

\section{Strat_age_min_hierarchy_crosstab_qry Query}

The Strat_age_min_hierarchy_crosstab_qry query (fig. 8) provides a tabular output showing the generalized age terms at each hierarchical level of age rankings (eon, era, period, subperiod, and epoch). [Labels for the column headings were modified in the Query Properties window for

\begin{tabular}{|c|c|c|c|c|c|c|c|}
\hline \multicolumn{6}{|c|}{ 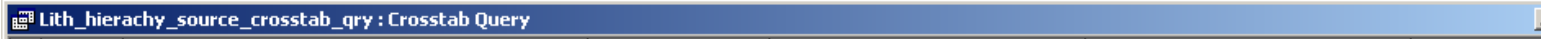 } & \multicolumn{2}{|c|}{$-|\square| x \mid$} \\
\hline \begin{tabular}{|l|l|} 
& MU_id \\
\end{tabular} & \begin{tabular}{|c|} 
Dominent Lithology \\
\end{tabular} & 1 & 2 & 3 & 4 & 5 & $\Delta$ \\
\hline 151 & volcanic QAPF rocks & igneous-volcanic & volcanic QAPF rocks & & & & \\
\hline 152 & andesitoid-rhyolitoid (calc-alkalic) volcanic suite & igneous-volcanic & volcanic QAPF rocks & andesitoid-rhyolitoid (calc-alkalic) & & & \\
\hline 153 & granitoid & igneous-plutonic & plutonic QAPF rocks & granitoid & & & \\
\hline 154 & granodiorite & igneous-plutonic & plutonic QAPF rocks & granitoid & granodiorite & & \\
\hline 155 & granodiorite & igneous-plutonic & plutonic QAPF rocks & granitoid & granodiorite & & \\
\hline 156 & mixed siliciclastic/carbonate sedimentary rocks & sedimentary rock & mixed siliciclastic/carbonate sed & & & & \\
\hline 157 & mixed siliciclastic/carbonate sedimentary rocks & sedimentary rock & mixed siliciclastic/carbonate sed & & & & \\
\hline 158 & mixed siliciclastic/carbonate sedimentary rocks & sedimentary rock & mixed siliciclastic/carbonate sed & & & & \\
\hline 160 & siliciclastic and carbonate sedimentary rocks & sedimentary rock & siliciclastic and carbonate sedim & & & & \\
\hline 161 & mixed siliciclastic/carbonate sedimentary rocks & sedimentary rock & mixed siliciclastic/carbonate sed & & & & \\
\hline 162 & mixed carbonate/siliciclastic sedimentary rocks & sedimentary rock & mixed carbonate/siliciclastic sed & & & & \\
\hline 163 & mixed siliciclastic/carbonate sedimentary rocks & sedimentary rock & mixed siliciclastic/carbonate sed & & & & \\
\hline 164 & mixed siliciclastic/carbonate sedimentary rocks & sedimentary rock & mixed siliciclastic/carbonate sed & & & & \\
\hline 165 & conglomerate & sedimentary rock & siliciclastic sedimentary rocks & siliciclastic rocks with gravel-sizeı & conglomerate & & \\
\hline 166 & siliciclastic sedimentary rocks & sedimentary rock & siliciclastic sedimentary rocks & & & & \\
\hline 167 & conglomerate & sedimentary rock & siliciclastic sedimentary rocks & siliciclastic rocks with gravel-sizeı & conglomerate & & \\
\hline 168 & conglomerate & sedimentary rock & siliciclastic sedimentary rocks & siliciclastic rocks with gravel-size & conglomerate & & -1 \\
\hline Record: 11 & $|4 \longdiv { 1 } \cdot| \boldsymbol{| l | l |}$ of 3451 & 1 & & 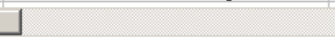 & & D & \\
\hline
\end{tabular}

Figure 6. Example of output from the Lith_hierarchy_source_crosstab_qry query.

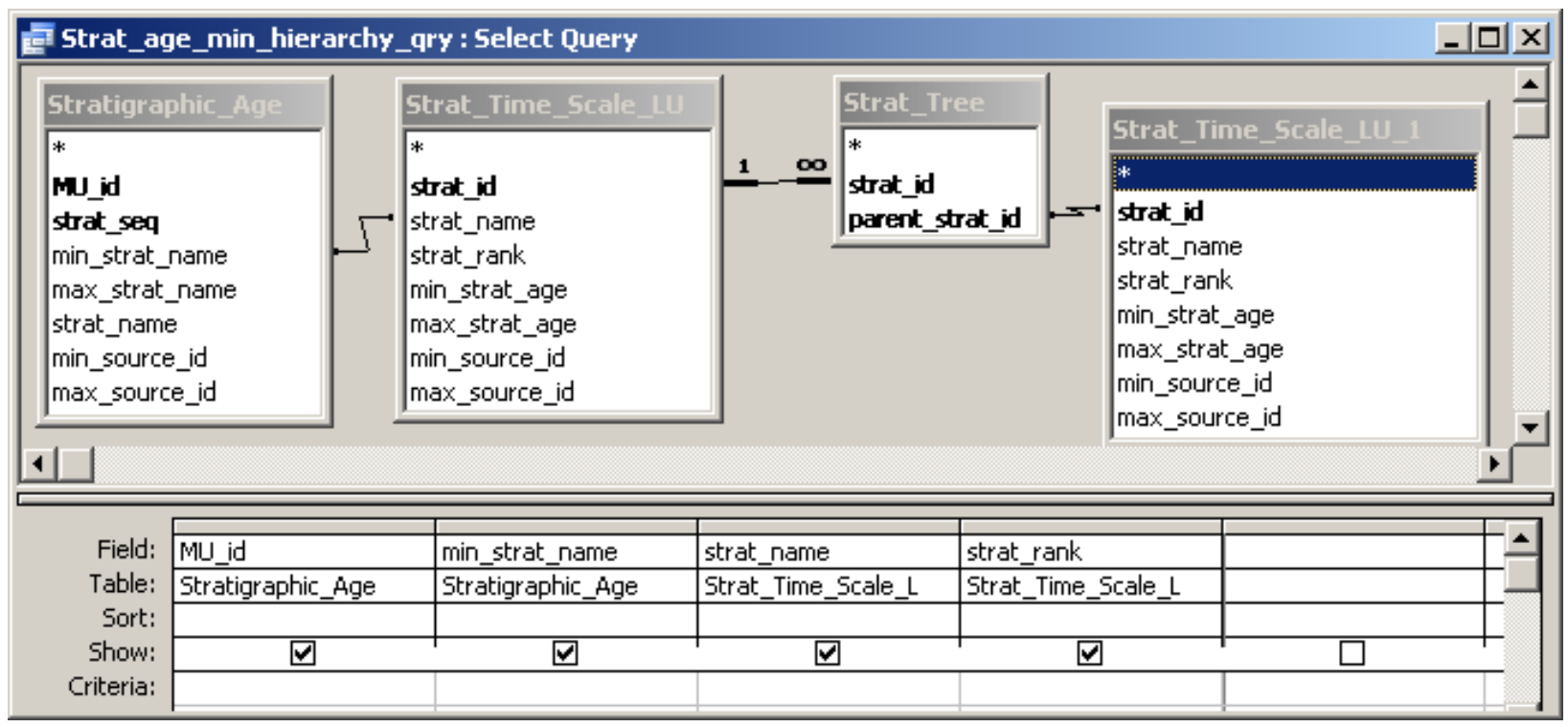

Figure 7. Design view of the Strat_age_min_hierarchy_qry query. 
the "Column Heading" entry in the "Crosstab:" row of the design view of the Strat_age_min_hierarchy_crosstab_qry query to produce a view showing the columns in a sequence of most general to most specific (from left to right) (fig. 9).]
The output will not display hierarchical-name attributes for all map units because not all age ranks have age names, and finer (more specific) age rankings may not have been designated in the source map-unit descriptions (fig. 10).

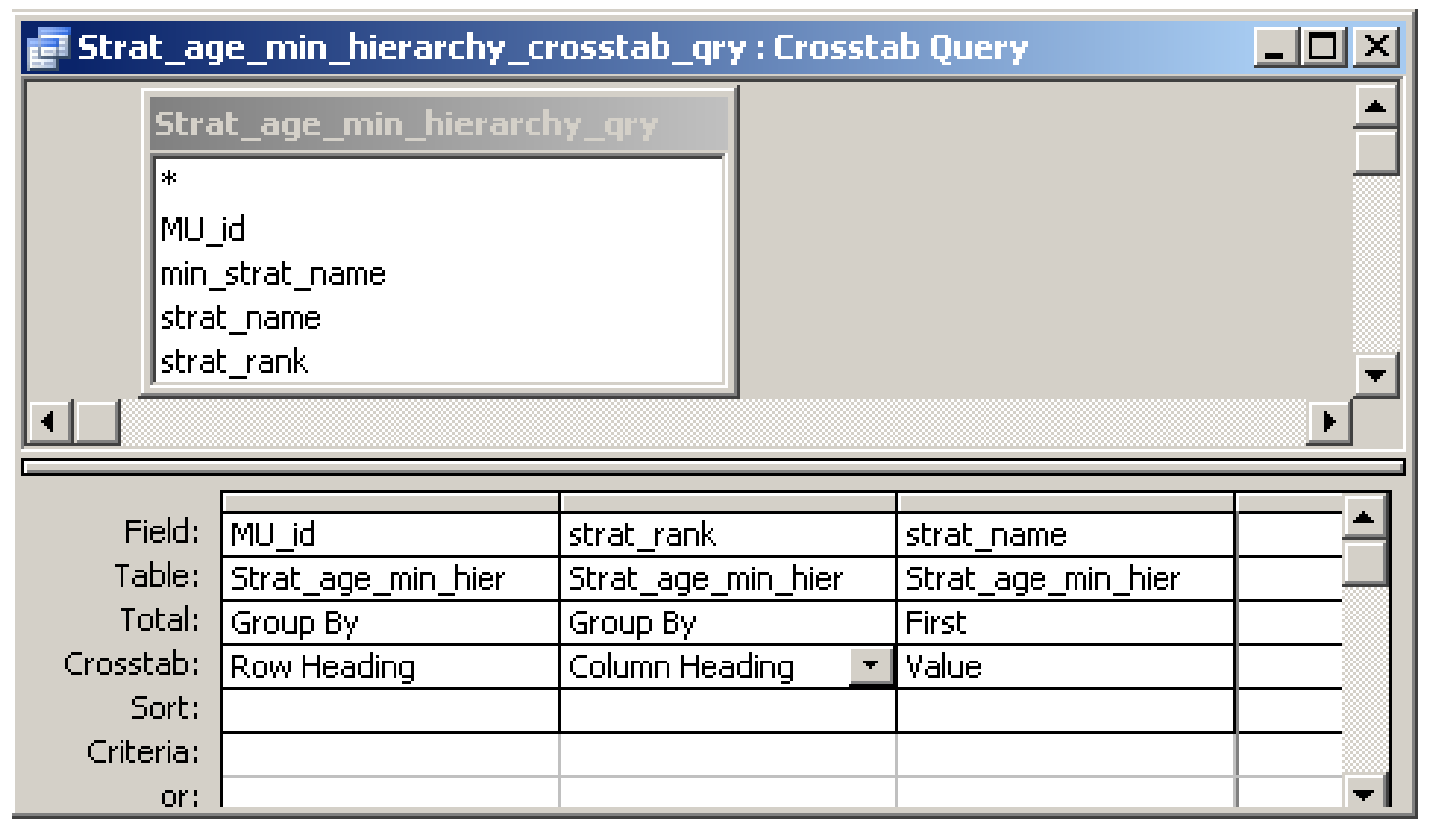

Figure 8. Design of the Strat_age_min_hierarchy_crosstab_qry query.

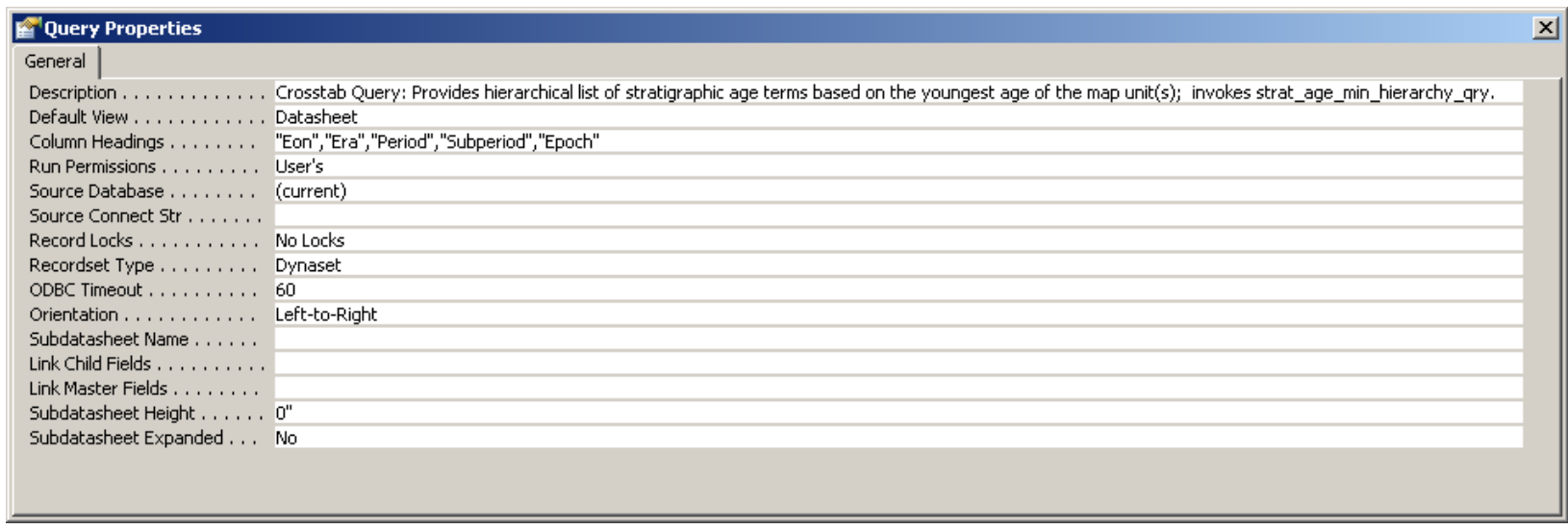

Figure 9. Query Properties window for the "Column Heading" entry in the "Crosstab:" row of the design view of the Strat_age_min_hierarchy_crosstab_qry query. (Shows entries used to designate columns headings in the output file.) 


\section{Database Forms}

There are 11 forms in the database: 2 main forms, $7 \mathrm{sub}$ forms, 1 startup form, and 1 splash screen form (fig. 11). One main form, NR_pdf_qry_frm, is used to create portable document format (PDF) files ${ }^{1}$. The other main form, MUO_frm, is for data input. One subform, NR_Bib_subfrm, is embedded in the NR_pdf_qry_frm form. The other subforms are embedded in the MUO_frm form.

\section{SplashScreen Form}

The SplashScreen form (fig. 12) displays when the nrgeo.mdb database is opened, and it lists product information (report title, authorship, date of publication, publisher, and publication series information). It appears for 5 seconds and then closes.

\section{1-Startup_frm Form}

The 1-Startup_frm form is a user-interface window (fig. 13) that automatically pops open after the introductory SplashScreen window closes. The buttons on this second window provide the user with an easy means of interacting with the database.

The button "Open Data Entry/View Form" opens the MUO_frm form, the button "Open Form to Print PDF" opens the NR_pdf_qry_frm form, the button "Run Age Parameter

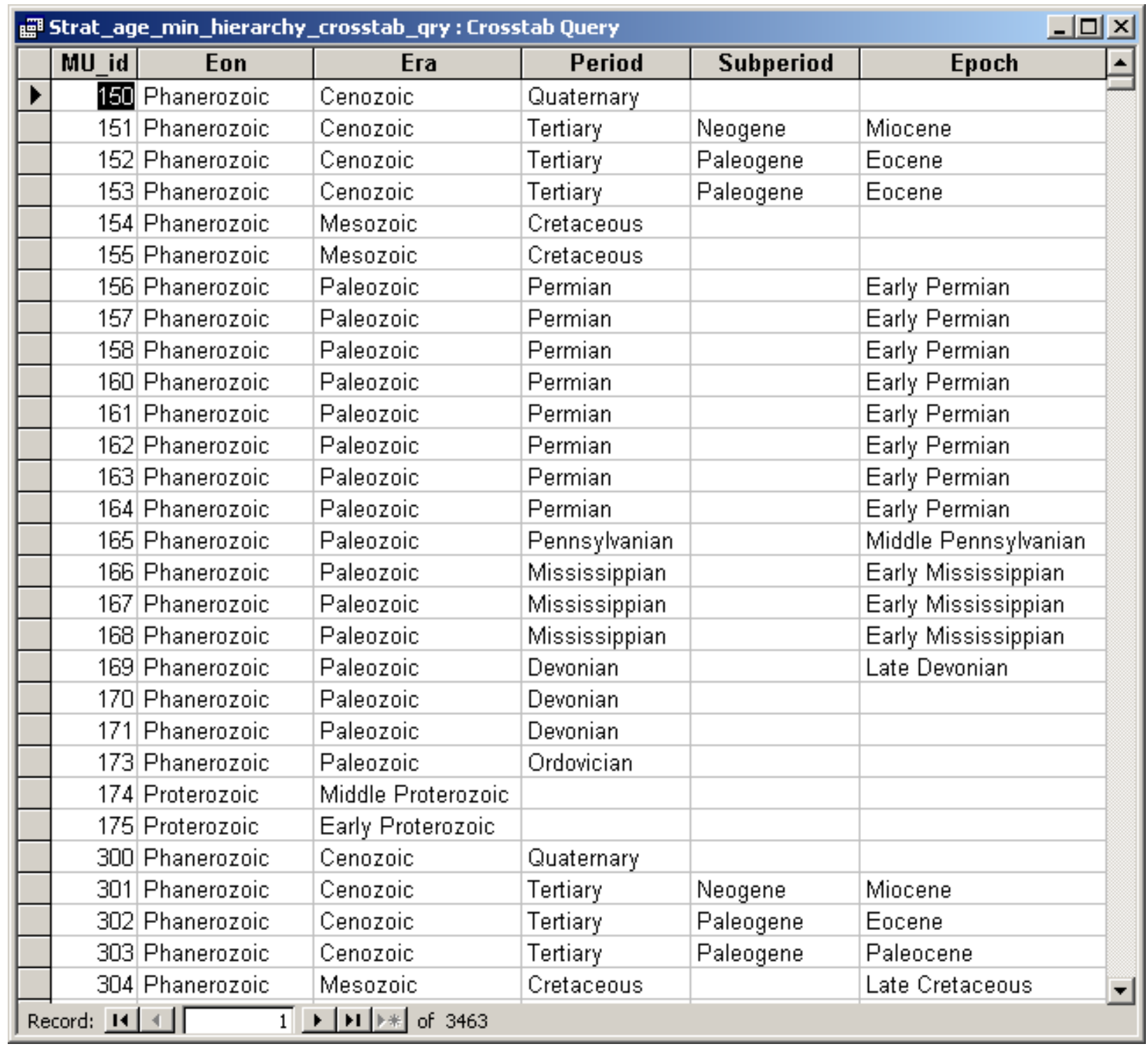

Figure 10. Example of output from the Strat_age_min_hierarchy_crosstab_qry query. 
Query" runs the Age_hierarchy_parameter_qry query, the button "Run Lithology Hierarchy Query" runs the Lith_hierachy_source_crosstab_qry query, the button "Run Strat Age Hierarchy Query" runs the Strat_age_min_hierarchy_crosstab_qry query, the button "Close This Form" closes the user-interface window, and the button "Close Database" closes the database and exits out of Access. The name (and a brief description) of the query or form that each button invokes is given in table 1 and fig. 11 .
NR_pdf_qry_frm Form

The NR_pdf_qry_frm form uses data from the NR_pdf_ qry query and the NR_pdf_Bib_subfrm form to provide the user with a view of descriptive information for each map-unit record in the database (fig. 14). Note that the entry in the text box for Description of Map Unit is truncated; only two lines of text are visible in the form as viewed onscreen. The data generated by using this form will, if printed to a PDF file, exceed

\begin{tabular}{|c|c|c|c|}
\hline \multicolumn{3}{|c|}{ nrgeo : Database (Access 2000 file format) } & \multirow[t]{2}{*}{$-|\square| x \mid$} \\
\hline \multicolumn{3}{|c|}{ 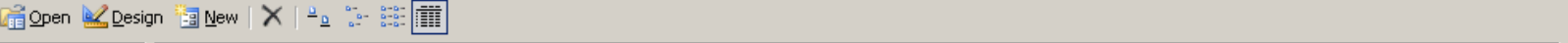 } & \\
\hline Objects & Name & & Description \\
\hline Tables & 墭 & 1-Startup_frm & Startup form \\
\hline 7 Oueries & 园 & MUO_frm & Master data entry form for MuO table (geologic map unit objects). \\
\hline I Querles & 圄 & MUO_Link_subfrm & Subform used on MUO_frm showing link between original map units and new units created for Northern Rocky Mountains geologic compilation. \\
\hline 园 Forms & 圆 & NR_Bib subfrm & Subform used on MUO_frm for input of data into NR_Bib table through the source_id code \\
\hline Reports & 圄 & NR_Lith_subfrm & Subform used on MOU_frm for input of data into NR_Lith table. \\
\hline Pages & 圈 & NR_pdf_Bib_subfrm & Subform used on NR_pdf_ary_frm to view references for each record. \\
\hline$\Rightarrow$ Macros & 䴗 & NR_pdf_qry_frm & Form used to output description of map units and related information to an Adobe PDF file published in Zientek and others (2005). \\
\hline Macros & 葍 & NR_Rock_Comp_subfrm & Subform used on MUO_frm for input of into NR_Rock_Composition table. \\
\hline Modules & 圄 & NR_Unit_Characteristic_subfrm & Subform used on MOU_frm for input of data into NR_Unit_Characteristics table. \\
\hline & 圆 & SplashScreen & Form displayed on Start-up showing publication credits. \\
\hline & & Stratigraphic_Age_subfrm & Subform used on MOU_frm for input of data into Stratigraphic_age table. \\
\hline Groups & 1 & & 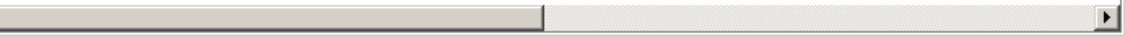 \\
\hline
\end{tabular}

Figure 11. Forms and their description in nrgeo.mdb database.

\section{Relational Database for the Geology of the Northern Rocky Mountains -}

\section{Idaho, Montana, and Washington}

J. Douglas Cauey, Michael L. Zientek, Arthur A. Bookstrom, Thomas P. Frost, Karl V. Evans,

Anna B. Wilson, BradleyS. VanGosen, David E. Bole neus, and Rebecca A. Pitts

U.S. Geological Surve y Data Se ries $-\mathrm{XXX}$

Figure 12. Window generated by the SplashScreen form. 
2,000 pages. The resultant PDF can be searched or printed out on paper. [The user must have the appropriate software to generate the PDF file for which this form was designed.]

To generate an easy-to-read print version of the descriptive information, the Detail properties (in the Format tab and the All tab of the form) for the line "Force New Page" are set to "After Section" so that no more than one record is printed per page (fig. 15). In addition, the properties for several of the text boxes on the form are set to "Yes" for the property "Can Grow" in order to print out the entire entry, and others are set to "Yes" for the "Can Shrink" property so as to not print out blank lines and waste paper. The "grow" or "shrink" proper-

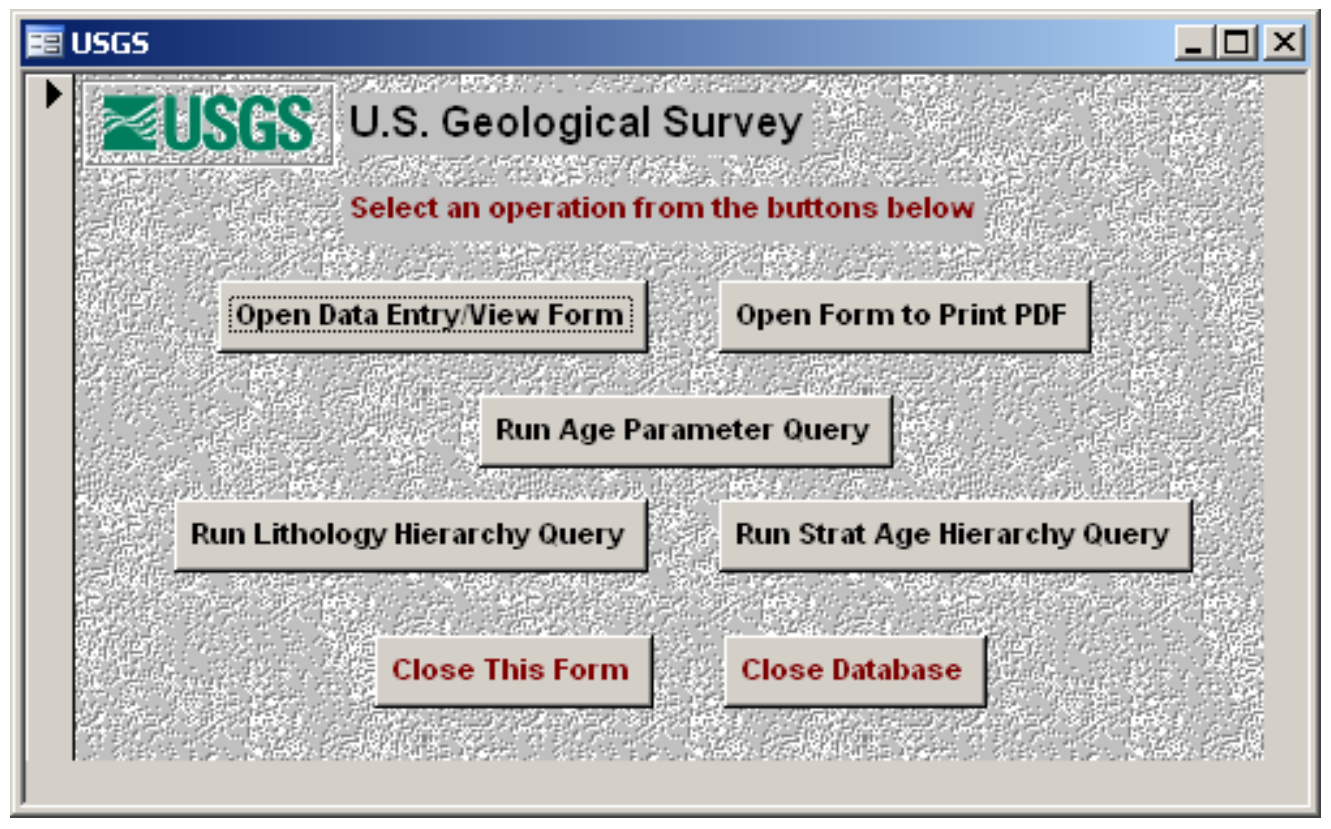

Figure 13. Window generated by the 1-Startup_frm form.

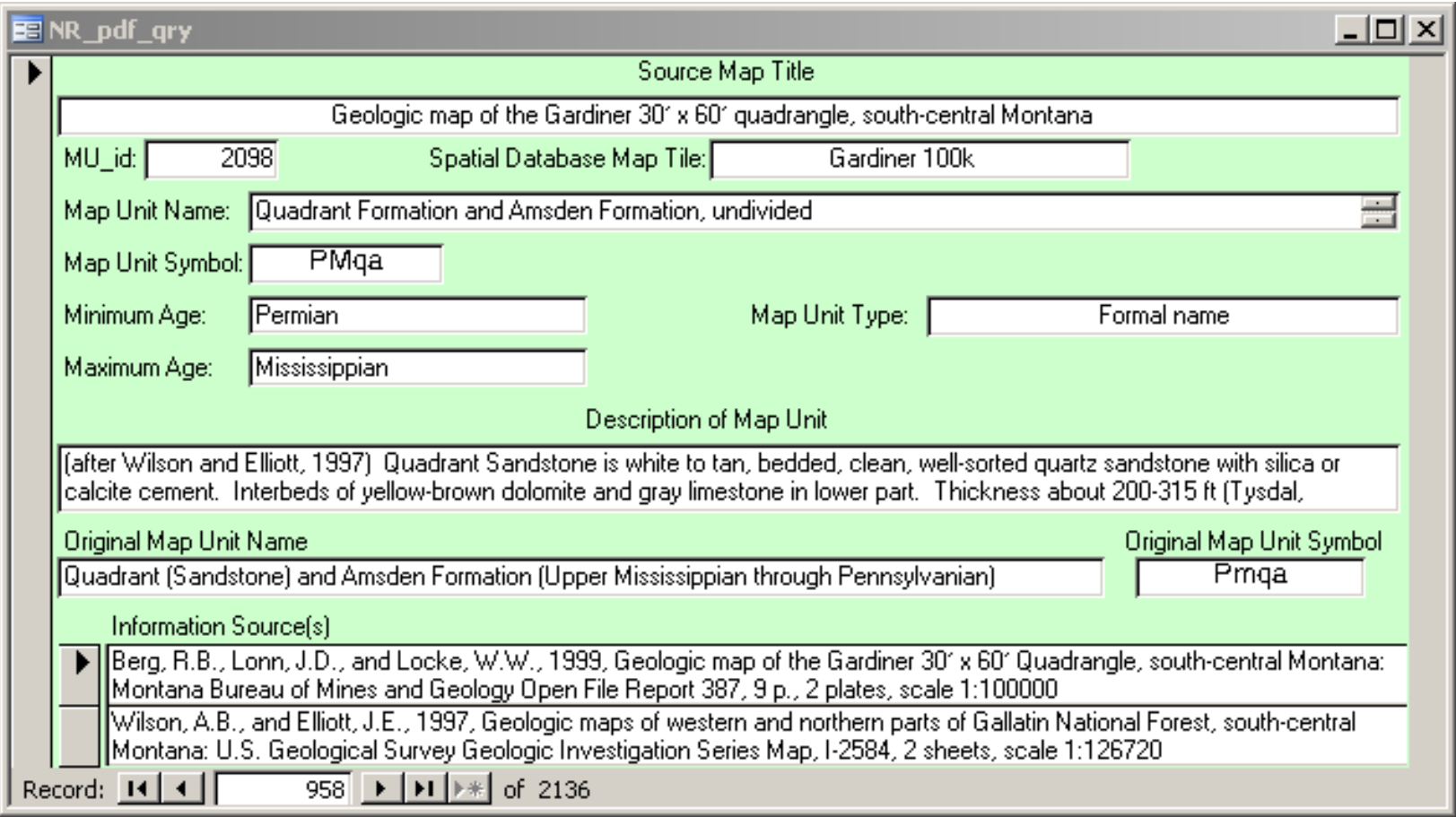

Figure 14. Example of the NR_pdf_qry_frm form. (Shows record for MU_id = 2098 in the nrgeo database.) 
ties are only activated when the form is printed (as opposed to displaying onscreen; compare figs. 14 and 16). For text boxes that have been set to expand on printing, vertical scroll bars will appear in the form when the user left-clicks in the box; the user can then scroll through the lines to view the entire entry onscreen (see text box for Map Unit Name in fig. 14).

\section{NR_pdf_Bib_Subfrm Form}

The NR_pdf_Bib_subfrm form (fig. 17) provides the mechanism to display multiple information sources for a single geologic-unit ( $M U_{-}$id) record on the NR_pdf_qry_ frm form (see fig. 14) by linking the source_id field in

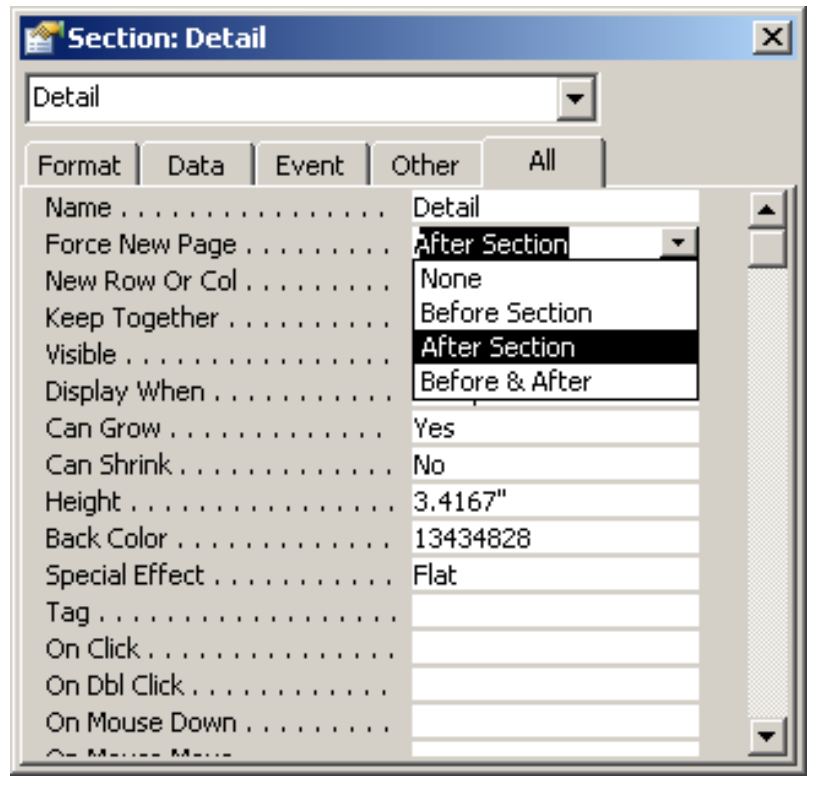

Figure 15. Properties for Detail section of Design view of the NR_pdf_qry_frm form.

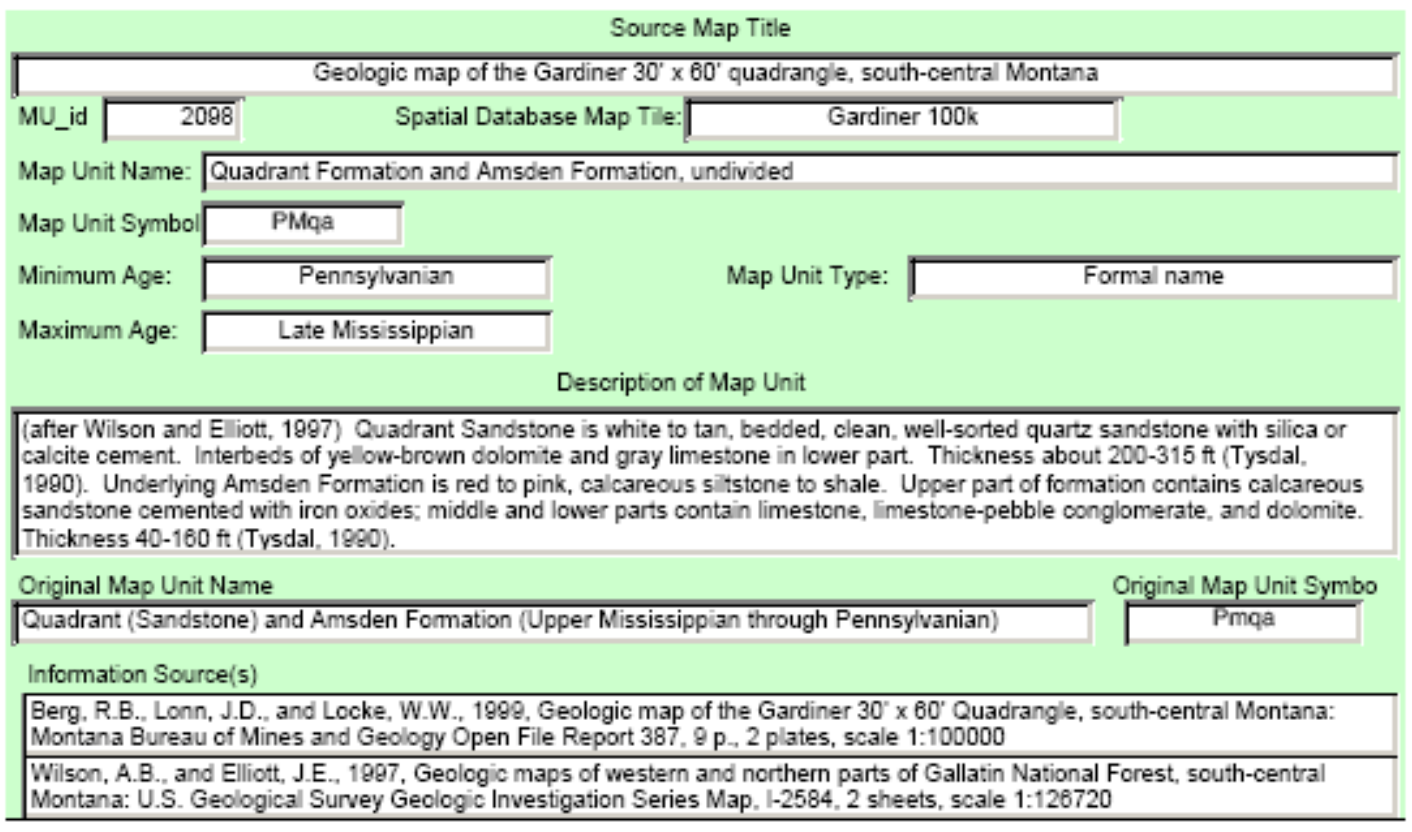

Figure 16. Example of printed output for $M U_{-} i d=2098$ demonstrating how the "Can Grow" property, when set to "Yes" for the "Description of Map Unit" text box, permits the entire description to be printed. 
the NR_Bib table to the source_id field in the NR_pdf_ qry query. Once the link is made, the subform is inserted into the NR_pdf_qry_frm form. The Detail properties for the Information Source(s) text box in the Design view of the subform is set to "Yes" for both of the lines "Can Grow" and "Can Shrink".

\section{MUO_frm Form}

The MUO_frm form (figs. 18A-E) is both a data entry form (for use only after a new map-unit record has been entered into the database by using the MUO table) and a data-viewing form. Descriptive information entered into this form is automatically distributed into the various other data tables by means of connections provided by embedded subforms and tabbed pages.
The shaded text boxes in the form (for example, MU_id, Source_id, and Original unit name) serve as visual clues that the data in them should not be revised or altered. Information in the various original unit boxes represents primary-source language and symbology. The data property for these boxes is set to prevent editing: "Locked" is set to "Yes" in the Data tab listings (fig. 19).

A description of the contents of each field in the form is displayed in the bottom of the Access database window frame (see fig. 18A). Clicking in any data window will show the associated text for that field.

Each of the five tabbed pages (occupying the lower half of the form) displays fields from a single related table, thus allowing the user to grasp a whole view of the data for a map unit while working on any one of the five related tables: the

\begin{tabular}{|c|c|c|}
\hline & NR_Bib_Subform & - $\square$ \\
\hline & Information Source & \\
\hline$\nabla$ & $\begin{array}{l}\text { Waggoner, S.Z., co } \\
\text { Geology and Earth } F\end{array}$ & ivision of \\
\hline
\end{tabular}

Figure 17. View of the NR_pdf_Bib_Subfrm form.

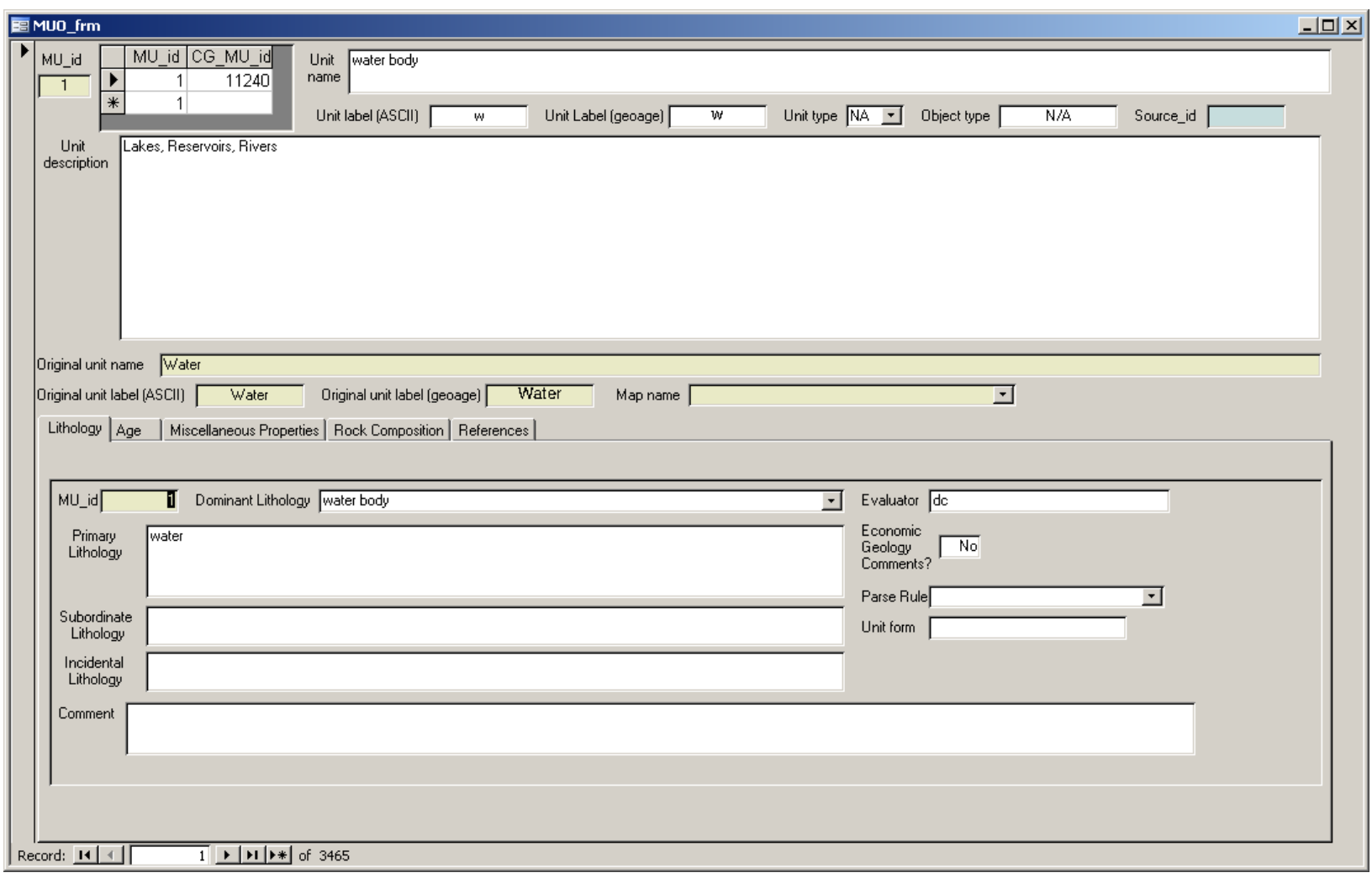

Figure 18A. View of the MUO_frm form. (The embedded MUO_Link_subfrm form displays as a correlation table in the upper left (between boxes for $\mathbf{M U}$ _id and Unit name); five page tabs positioned along a central horizontal represent five more embedded forms; the Lithology-tabbed page is open.) 


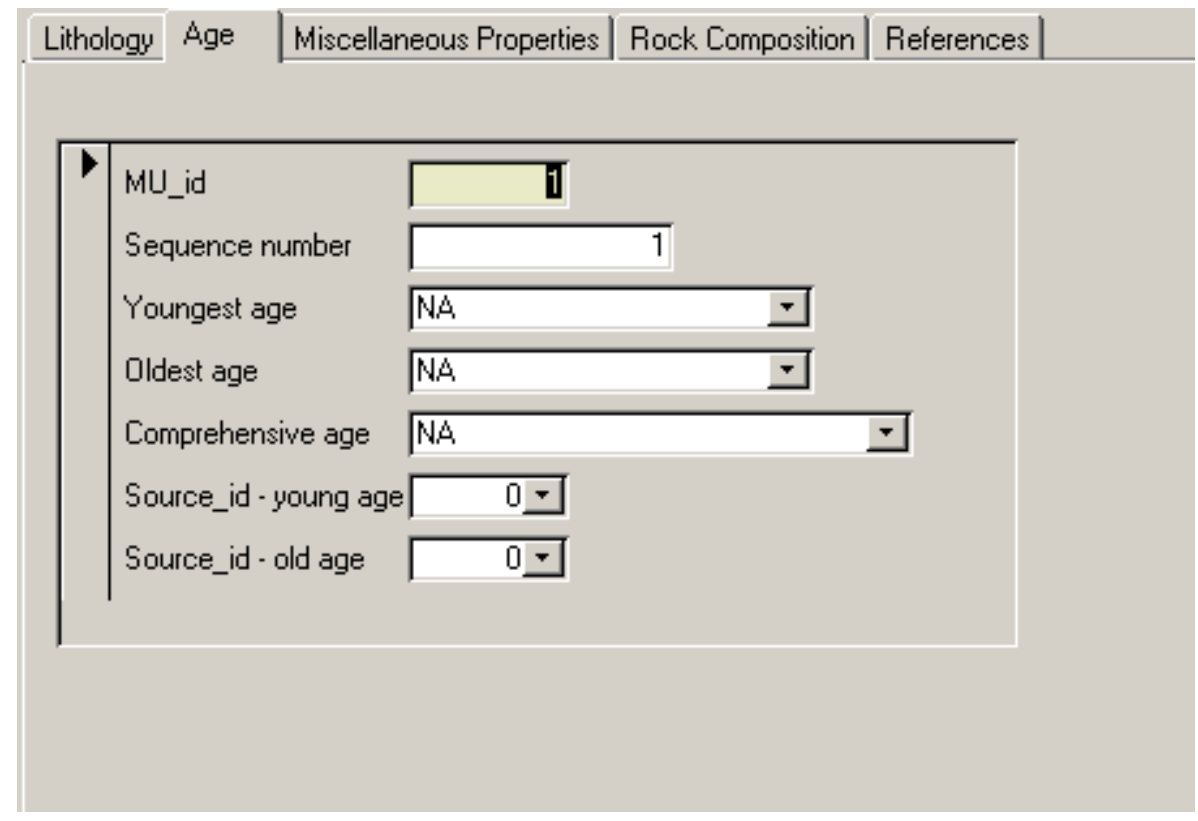

Figure 18B. View of layout for the Age-tabbed page in MUO_frm form.

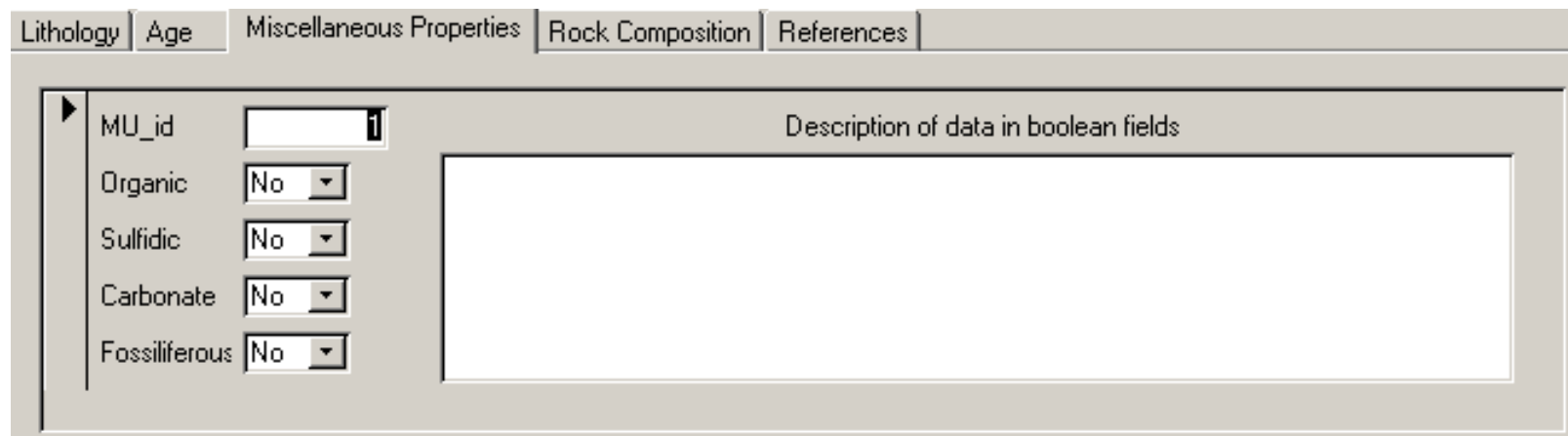

Figure 18C. View of layout for the Miscellaneous Properties-tabbed page in the MUO_frm form.

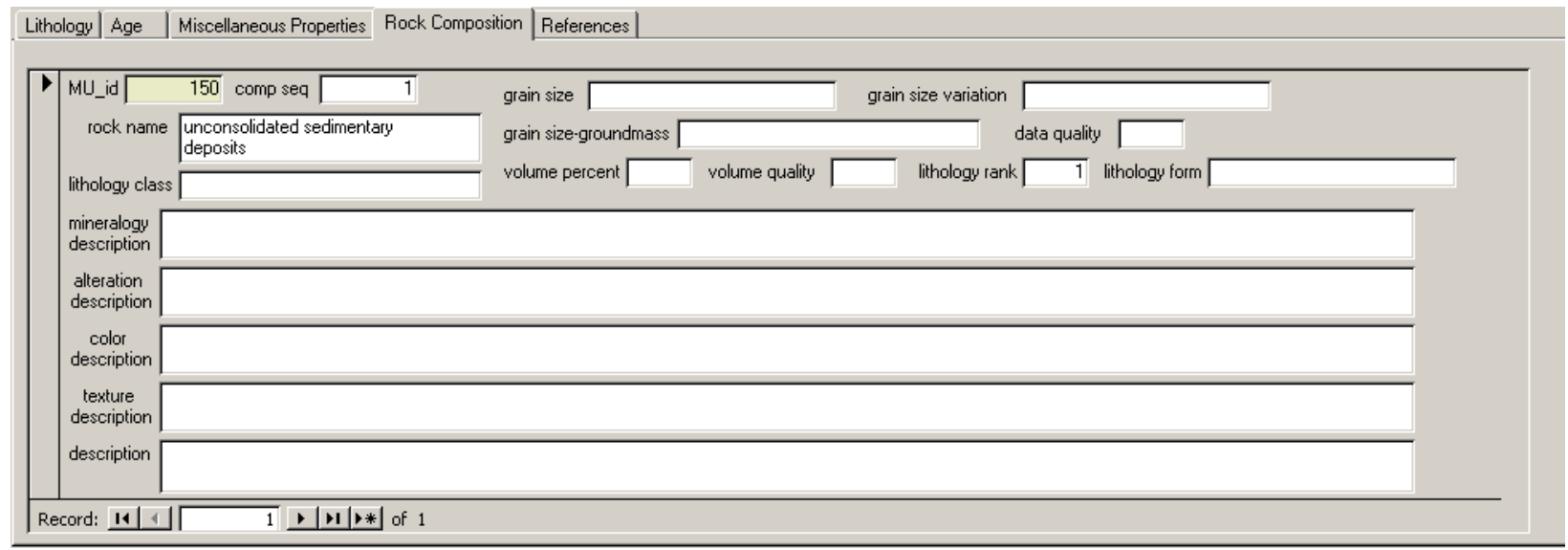

Figure 18D. View of layout for the Rock Composition-tabbed page in the MUO_frm form. 
Lithology page points to the NR_Lith table, Age points to the Stratigraphic_Age table, Miscellaneous Properties to the NR_Unit_Characteristic table, Rock Composition to the NR_Rock_Comp table, and References to the NR_Bib table.

\section{MUO_Link_subfrm Form}

The MUO_Link_subfrm form (fig. 20) displays the correlation between the map-unit identifier for the original map unit $\left(M U_{-} i d\right)$ and the map-unit identifier for the compiled geologic-map unit $\left(C G \_M U \_i d\right)$ from the MUO_Link table.

\section{NR_Bib subfrm Form}

The NR_Bib subfrm form (fig. 21) is displayed on the References-tabbed page of the MUO_frm form and contains text boxes for all the fields in the NR_Bib table. The data is linked to records in the MUO table by the source_id field (which should never be edited or revised in this form). Data entered in this form follow standards set by the USGS. If the cited publication is part of another publication, then the larger-work information (author and title) is entered into the text boxes designated LW1 for first larger work and LW2 for second larger work (where LW1 would be nested inside the larger work LW2).

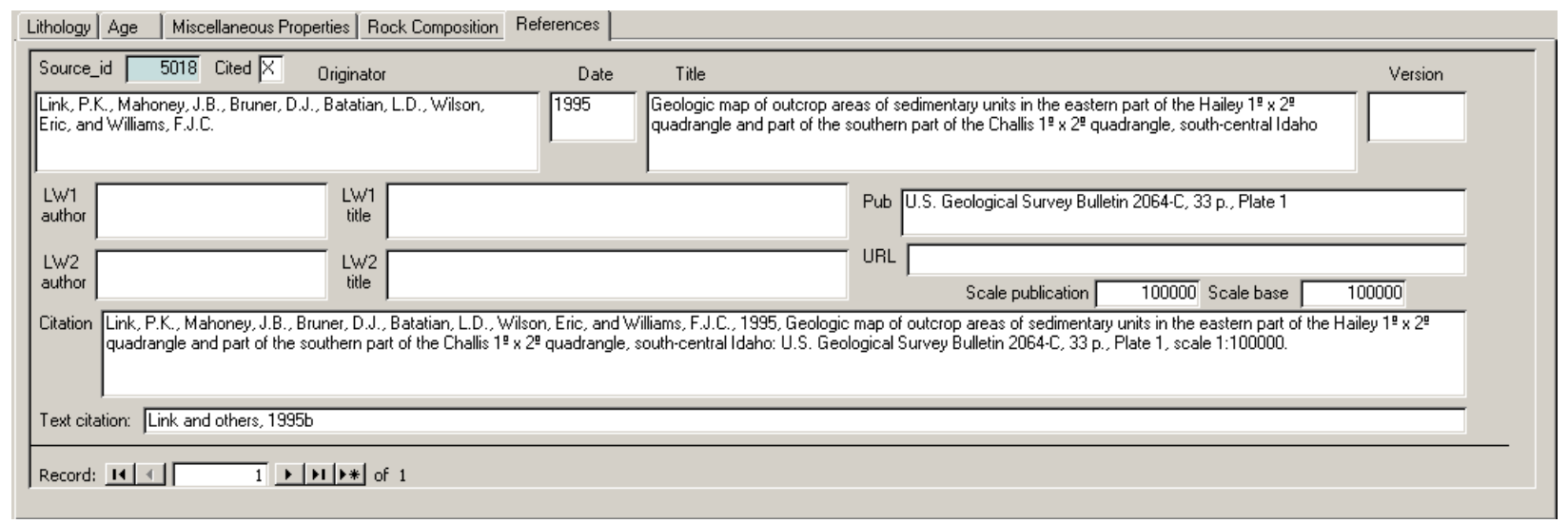

Figure 18E. View of layout entries for the References-tabbed page in the MUO_frm form.

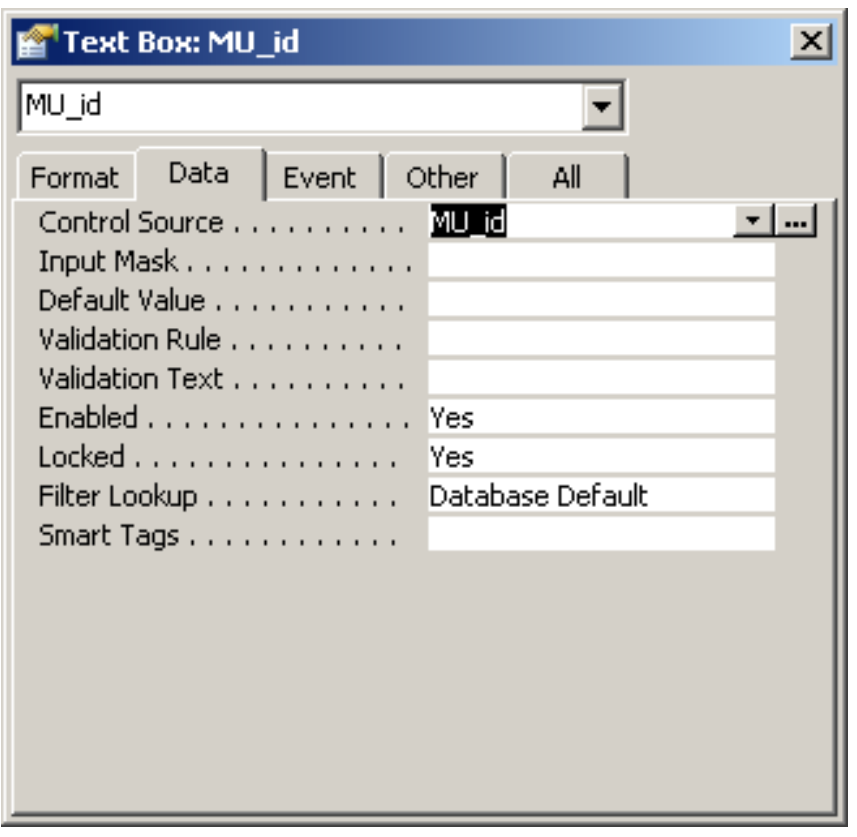

Figure 19. Properties for Text Box MU_id on the Data tab of the Design view of the MUO_frm form. (Note "Locked" on the Data tab is set to "Yes" to keep users from modifying the entry for MU_id.

\begin{tabular}{|c|c|c|c|}
\hline E回 & UD_link s & - & $\mathbf{x}$ \\
\hline & MU_id & CG_MU_id & $\Delta$ \\
\hline 1 & 1 & 11240 & \\
\hline & 150 & 11126 & \\
\hline & 151 & 10722 & \\
\hline & 157 & 1חרא. & $\nabla$ \\
\hline
\end{tabular}

Figure 20. MUO_Link_subfrm form. (For example, it shows that the original map unit with $\mathbf{M U}$ id = 1 correlates to the compiled geologicmap unit with CG_MU_id = 11240, for the selected unit.) 
This form can be used by itself to enter new references into the database or view existing records. The database contains many references that were acquired by scanning the references lists from the source-map publications and from other sources related to the geology of the northern Rocky Mountain region.

\section{NR_Lith_subfrm Form}

The NR_Lith_Subfrm form (fig. 22) is embedded in the MUO_frm form (on the Lithology tab, fig. 18A) for entering or editing lithologic data in the NR_Lith table. The NR_Lith subfrm form was not designed for use as a standalone dataentry form; thus, navigation buttons on the form were removed to prevent the user from attempting data entry outside of the MUO_frm form environment.

\section{NR_Rock_Comp_subfrm Form}

The NR_Rock_Comp_subfrm form (fig. 23) comprises the Rock Composition-tabbed page in the MUO_frm form;

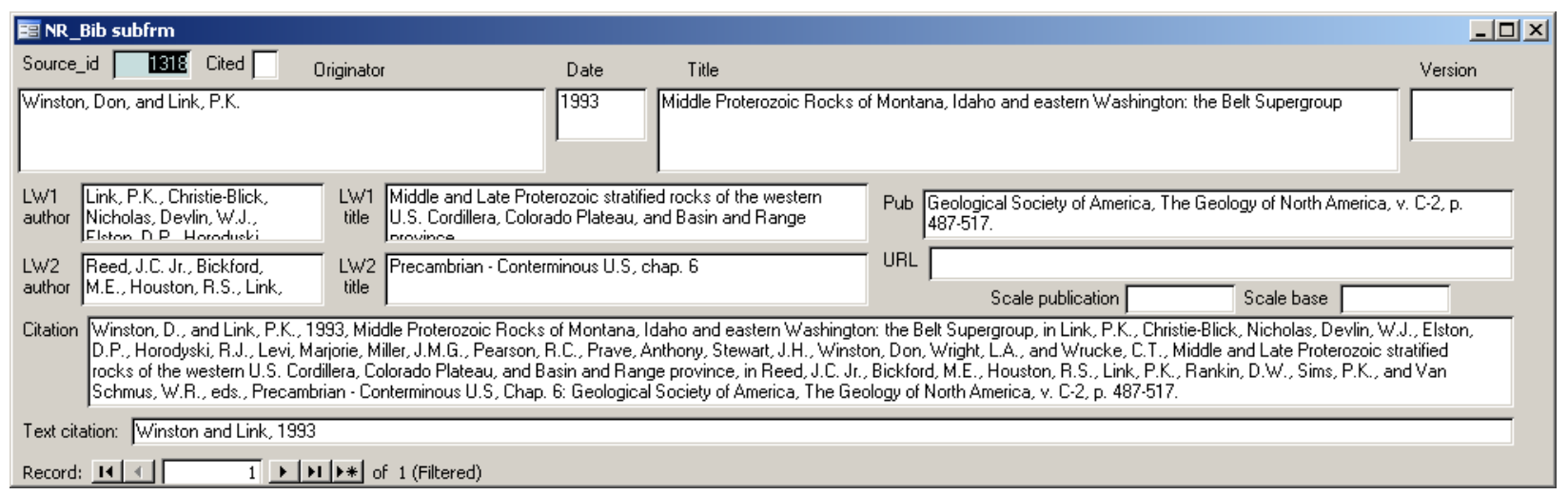

Figure 21. NR_Bib subfrm form.

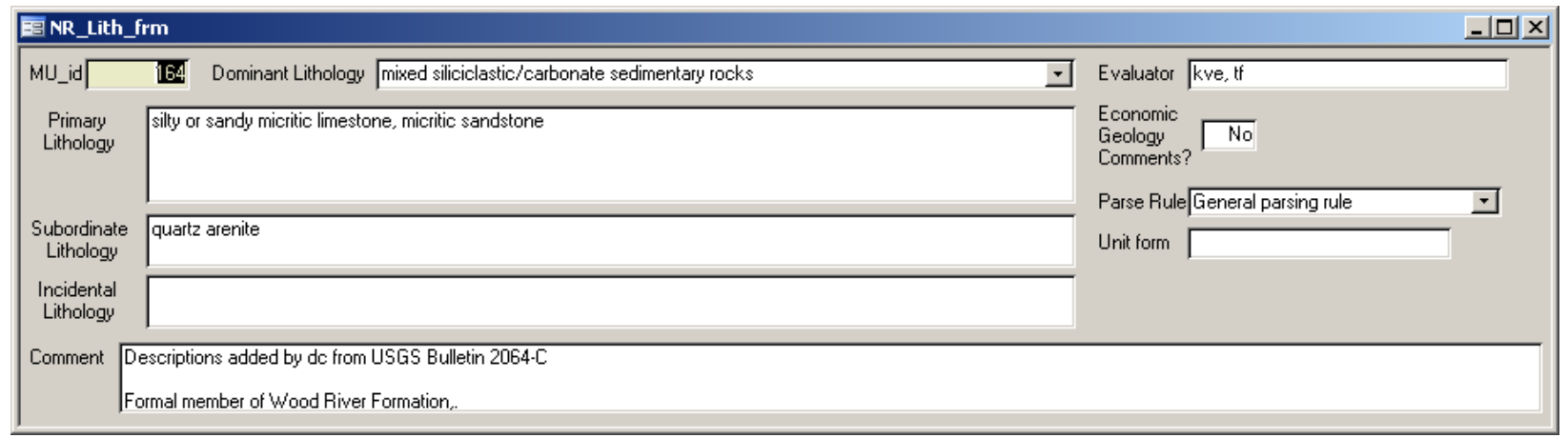

Figure 22. NR_Lith_subfrm form.

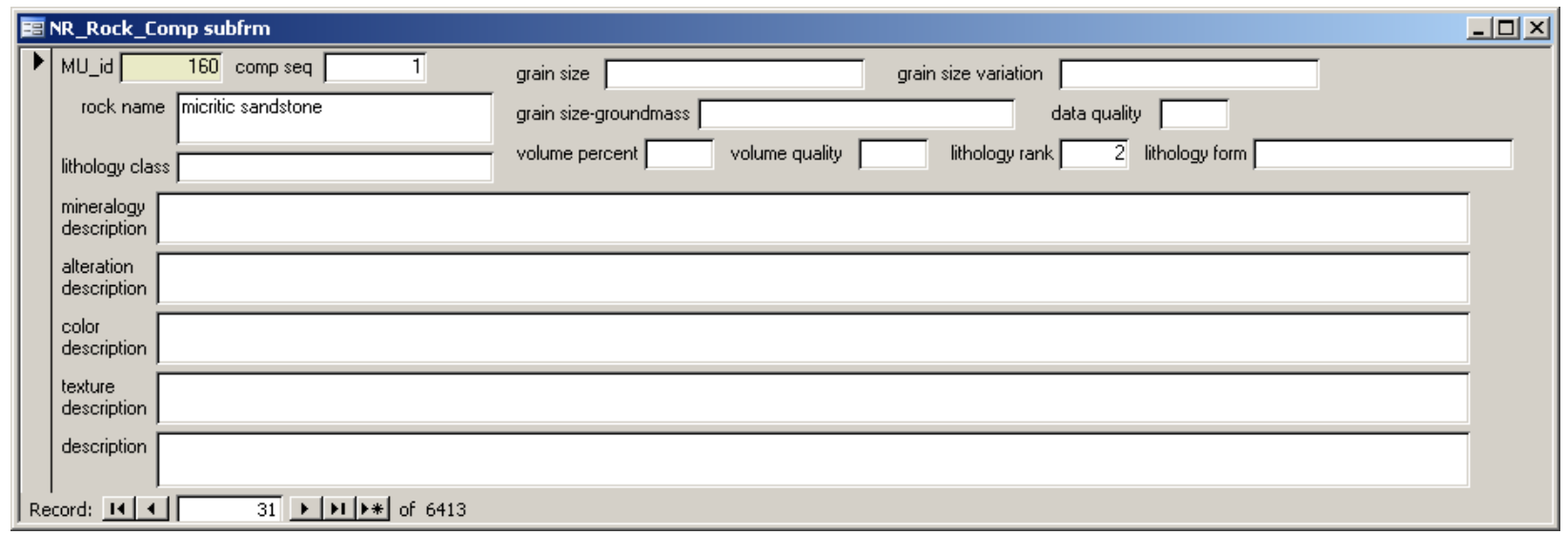

Figure 23. NR_Rock_Comp_subfrm form. 
the form may be used to enter descriptive information about the mineralogy and alteration of map units in the NR_Rock_ Comp table. No information other than $M U_{-} i d$, composition sequence number, rock name, and lithology ranking was entered into the nrgeo database; the other data fields are empty and available for future attribution.

\section{NR_Unit_Characteristic_subfrm Form}

The NR_Unit_Characteristic_subfrm form (fig. 24) comprises the Miscellaneous Properties-tabbed page embedded in the MUO_frm form Data entered into this tabbed page are stored in the NR_Unit_Characteristic table.

\section{Stratigraphic_Age_subfrm Form}

The Stratigraphic_Age_subfrm form (fig. 25) comprises the Age-tabbed page that is embedded in the MUO_frm form. Data entered into this tabbed page are stored in the Stratigraphic_Age table. This entry form is used to document the youngest and oldest stratigraphic ages of a map unit. It also contains a term (in the text box for Comprehensive age) that expresses the age range in geologic-period or higher-level age terms. The Comprehensive-age term should reflect geologic period when the age represents a period or a level lower than period, and era when the age term is a level higher than period, but lower or equal to era in rank.

\section{Conclusions}

The relational database nrgeo.mdb contains detailed information for 3,465 geologic-map units (2,136 units from source maps and 1,329 units from a regional-map compilation) used in creating a GIS for the geology of the northern Rocky Mountains. Data was entered into the relational database in order to structure it in a consistent format, perform qualitycontrol checks, and export selected data for incorporation into the spatial database nr_geo of Zientek and others (2005).

A digital geologic database provides a mechanism to produce a consistent description of geology and consolidate diverse descriptions from many authors. Spelling errors can be prevented and quality controls can be used to check for some kinds of errors. A benefit of relational databases is that the geologist is not limited in describing geologic characteristics to one set or view of temporal-physical-chemical parameters. Another advantage of databases over paper maps is the ability to rapidly create generalized products for types of information that are hierarchical, such as stratigraphic time and rock types.

A relational database combined with a spatial database provides a mechanism to create a variety of maps that present differing views of geology. The database provided with this report was used in the production of the spatial database (nr_geo) by Zientek and others (2005), and it also contains additional information. Figures 26 through 29 are examples of

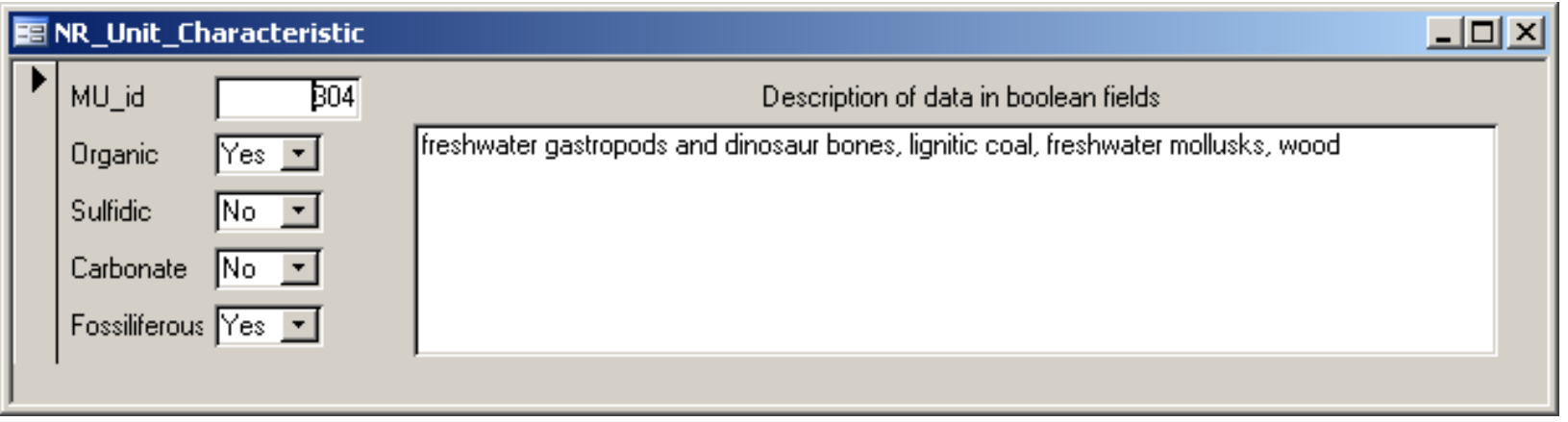

Figure 24. NR_Unit_Characteristic_subfrm form.

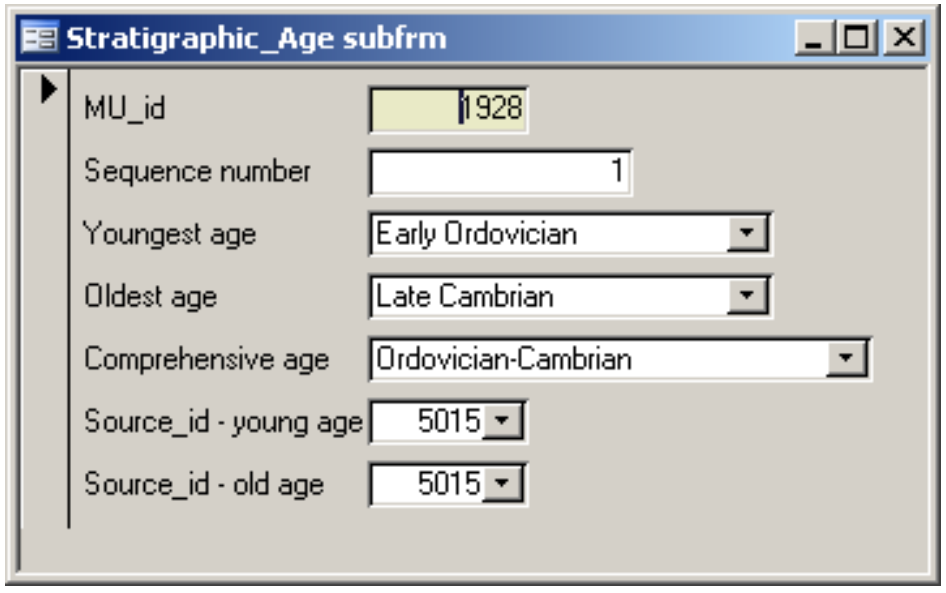

Figure 25. Stratigraphic_Age_subfrm form. 
some of the types of maps that can be made by combining this database with the associated spatial database.

Geologic maps usually reflect the emphases of their authors, illustrating different goals, purposes, and interests. Paper geologic maps are limited to a two-dimensional product that often tries to provide the user with multidimensional information. These limitations can present difficulties when using nondigital, published geologic maps to produce a database that contains consistent descriptions across several mapped areas. When diverse source map materials are compiled, these difficulties are exacerbated. For example, editors/authors of adjoining maps may combine geologic units in different groupings, emphasize different ages or different rock types, and provide differing styles of rock-unit descriptions. As is shown in figures 27 and 28, these differences create distinct breaks across some map boundaries, which reflects the inconsistency in map-unit descriptions.

In this endeavor it was not always possible to code information for map units so that a user could produce a consistent two-dimensional map product for each of the classes of data stored in the database. For example, on one of the source maps an author may have lumped all Paleozoic sedimentary formations into one map unit with little or no description of the rocks, while on an adjoining map, units in each geologic period of the Paleozoic may have been individually identified and described. By using the data in this database to make a map based on geologic era for example, a consistent product could be created; however, attempting to display the geologic units by geologic period may result in a "fault" at the source-map boundaries (fig. 26). This type of apparent mismatch can occur for almost every type of information included in this database.

Despite the limitations just described, many useful map compilations can be created from the database. Lithology and age have been standardized. Difficulties with the data can be easily seen when this database is attached to the $\mathbf{n r}$ geo database of Zientek and others (2005), thereby giving the user a visual display so that the problem areas can be easily identified and fixed.

\section{References Cited}

Haq, B.U., and Van Eysinga, F.W.B., 1998, Geological time table, 5th revised edition: New York, Elsevier Science.

Johnson, B.R., Brodaric, Boyan, Raines, G.L., Hastings, J.T., and Wahl, Ron, 1999, Digital geologic map data model, version 4.3: U.S. Geological Survey web publication, 69 p. [http://www.nadm-geo.org/prd/Model43a.pdf, last accessed August 20, 2008].
Larsen, J.C., Assmus, K.C., Causey, J.D., and Zientek, M.L., 2004, Rectified images of selected geologic maps in the northern Rockies area, Idaho, Montana, Washington, and Wyoming: U.S. Geological Survey Digital Series 106, 17 p. [http://pubs.usgs.gov/ds/106/, last accessed August 20, 2008].

North American Geologic Map Data Model (NADM) Steering Committee Data Model Design Team, 2004, NADM Conceptual model 1.0-A conceptual model for geologic map information: U.S. Geological Survey Open-File Report 2004-1334, 60 p. [http://pubs.usgs. gov/of/2004/1334/2004-1334.pdf, last accessed August 20, 2008].

Palmer, A.R., 1998, A proposed nomenclature for stages and series for the Cambrian of Laurentia: Canadian Journal of Earth Sciences, v. 35, p. 323-328.

Palmer, A.R., and Geissman, John, comps., 1999, 1999 geologic time scale: The Geological Society of America, 1 p. [http://www.geosociety.org/science/timescale/ timescl.pdf, last accessed August 20, 2008].

Remane, Jurgen, comp., 2003, International stratigraphic chart: UNESCO, [http://www.iugs.org/iugs/pubs/intstratchart.htm, last accessed March 20, 2003].

Hansen, W.R., ed., 1991, Suggestions to authors of the reports of the United States Geological Survey: Washington, D.C., U.S. Government Printing Office, 289 p.

Wilson, A.B., 2001, Compilation of various geologic time scales: U.S. Geological Survey Open-File Report 01-0052, v. 1, including an Excel spreadsheet [http:// pubs.usgs.gov/of/2001/ofr-01-0052/geologictime.xls], [http://pubs.usgs.gov/of/2001/ofr-01-0052/geologictimescale.html, last accessed August 20, 2008].

Zientek, M.L., Derkey, P.D., Miller, R.J., Causey, J.D., Bookstrom, A.A., Carlson, M.H., Green, G.N., Frost, T.P., Boleneus, D.E., Evans, K.V., Van Gosen, B.S., Wilson, A.B., Larsen, J.C., Kayser, H.Z., Kelley, W.N., and Assmus, K.C., 2005, Spatial databases for the geology of the northern Rocky Mountains-Idaho, Montana, and Washington: U.S. Geological Survey Open File Report 2005-1235, [http://pubs.usgs.gov/of/2005/1235/, last accessed August 20, 2008]. 

Figures 26-29 


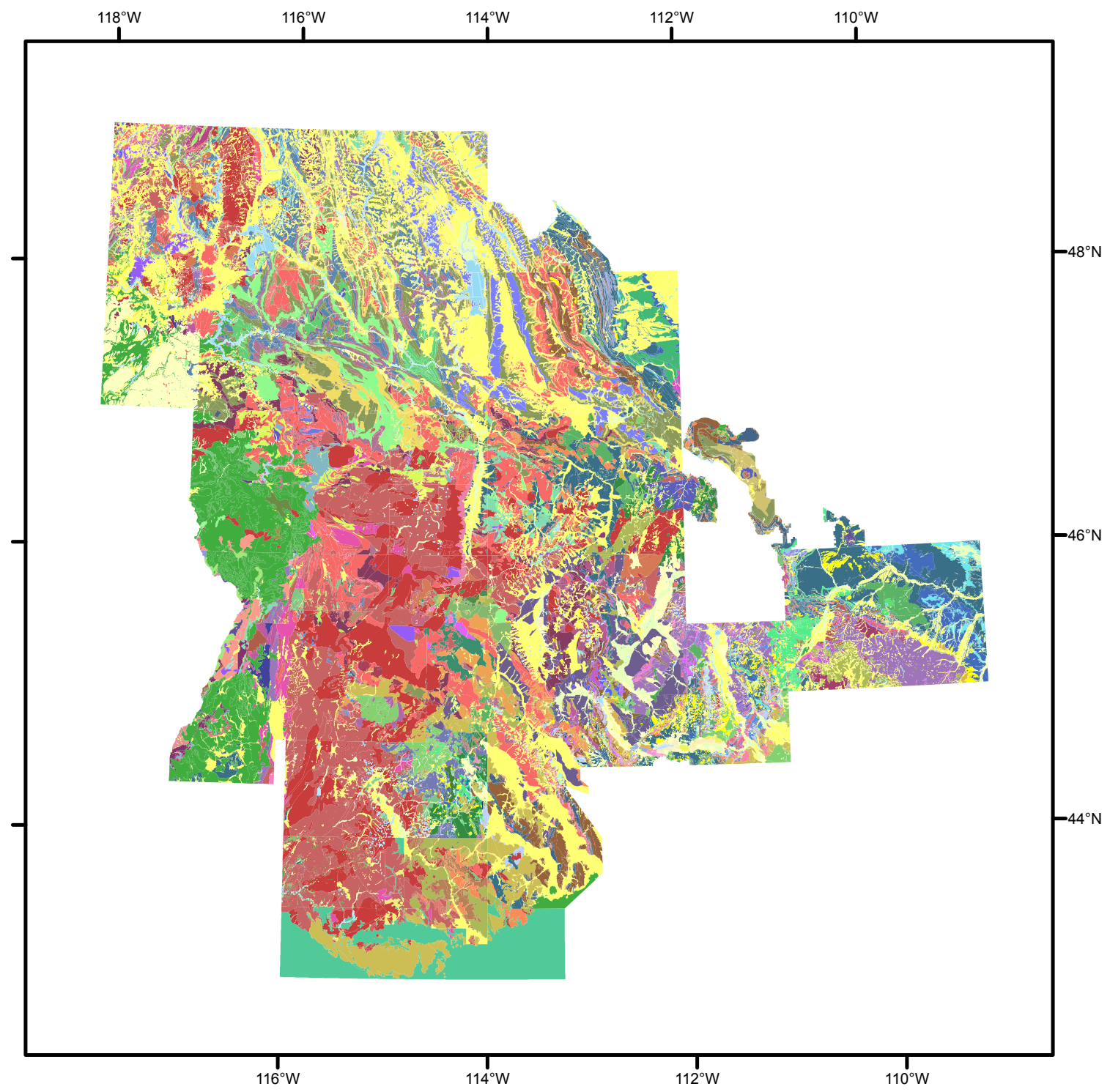

Figure 26. Dominant-lithology map of the northern Rocky Mountains. 


\begin{tabular}{|c|c|c|}
\hline & Legend & \\
\hline alluvial fan and fan deltas & made ground & monzonite \\
\hline amphibolite & mafic gneiss & monzonitoid-granitoid (alkali-calcic) plutonic suite \\
\hline andesite & mafic igneous rock & mudrock (shale) \\
\hline andesitoid/basaltoid & mafic metavolcanic rocks & mudstone or mud-shale \\
\hline andesitoid-rhyolitoid (calc-alkalic) volcanic suite & marble & mylonite \\
\hline anorthosite & meta-argillaceous carbonate & natural unconsolidated sediments \\
\hline anthropogenic unconsolidated sediments & meta-argillaceous dolomite & older alluvium \\
\hline argillaceous carbonate & meta-calcareous siltstone or claystone & orthopyroxenite \\
\hline argillaceous dolomite & meta-claystone & peat \\
\hline argillaceous limestone & meta-diorite & peridotite \\
\hline basalt & meta-dioritoid/gabbroid/anorthosite & phyllite - composition unknown \\
\hline black shale & meta-dolomitic siltstone or claystone & plutonic QAPF rocks \\
\hline calcareous sandstone & meta-dolostone (dolomite) & porphyry \\
\hline calcareous siltstone or claystone & meta-feldspathic arenite & pyroxene peridotite \\
\hline calcsilicate rock & meta-feldspathic wacke & pyroxenite \\
\hline carbonate and siliciclastic sedimentary rocks & meta-gabbro & quartz diorite \\
\hline carbonate sedimentary rocks & meta-granite & quartz latite \\
\hline carbonate-bearing siltstone or claystone & meta-granitoid & quartz monzodiorite \\
\hline cataclasite & meta-granodiorite & quartz monzonite \\
\hline cherty limestone & meta-monzogranite & quartz syenite \\
\hline colluvium & meta-mudrock (shale) & quartz-arenite \\
\hline conglomerate & meta-peridotite & quartzofeldspathic rock \\
\hline dacite & meta-quartz diorite & residual material \\
\hline dacitoid & meta-quartz gabbro & rhyodacite \\
\hline diorite & meta-quartz-arenite & rhyolite \\
\hline dioritoid/gabbroid/anorthosite & meta-sandstone or arenite & rhyolitoid \\
\hline dioritoid-granitoid (calc-alkaline) plutonic suite & meta-sandy carbonate & sandstone or arenite \\
\hline dioritoid-granitoid (calc-alkaline) plutonic suite & meta-siliciclastic rocks with gravel-sized particles & sandy limestone \\
\hline dolomite & meta-siltstone & semi-pelitic rock \\
\hline dolomitic limestone & meta-syenitoid & sheet gravels \\
\hline dolomitic sandstone & meta-tonalite & siliceous limestone \\
\hline dolomitic siltstone or claystone & | meta-volcaniclastic sedimentary rocks & siliciclastic and carbonate sedimentary rocks \\
\hline eolian deposits (eluvium) & meta-wacke & siliciclastic rocks with gravel-sized particles \\
\hline epiclastic conglomerate & | metamorphic and igneous plutonic rocks & siliciclastic sedimentary rocks \\
\hline epiclastic mudrock & metamorphosed aluminous and sub-aluminous rocks & slumps and landslides \\
\hline epiclastic sandstone & metamorphosed andesitoid-rhyolitoid (calc-alkalic) volcanic suite & subarkose (subfeldspathic arenite) \\
\hline epiclastic sedimentary rocks & metamorphosed calcareous rocks & syenite \\
\hline foid syenitoid & metamorphosed carbonate and siliciclastic sedimentary rocks & syenitoid \\
\hline gabbro & metamorphosed carbonate sedimentary rocks & $\begin{array}{l}\text { talus slopes, colluvial mantles, snow avalanche } \\
\text { deposits, rockslide debris }\end{array}$ \\
\hline glacial sediments & | metamorphosed iron formation or iron stone & tectonic breccia \\
\hline glaciated valley & metamorphosed mafic igneous rock & tectonic mélange \\
\hline glaciofluvial & metamorphosed mafic or basic rocks & tectonite \\
\hline glaciolacustrine & metamorphosed magnesian rocks & terrace deposits \\
\hline granite & metamorphosed mixed carbonate/siliciclastic sedimentary rocks & tonalite \\
\hline granitoid & metamorphosed mixed siliciclastic/carbonate sedimentary rocks & trachyandesite (TAS) \\
\hline granodiorite & | metamorphosed plutonic QAPF rocks & trachybasalt (TAS) \\
\hline greenschist & metamorphosed plutonic ultramafic rock & trachyte \\
\hline greenstone (metavolcanic) & metamorphosed sedimentary and metamorphosed volcanic rocks & trachytoid \\
\hline hornblende gabbro & metamorphosed siliceous rocks & travertine \\
\hline igneous plutonic and metamorphic rocks & metamorphosed siliciclastic and carbonate sedimentary rocks & tuffaceous mudstone \\
\hline jasper & metamorphosed siliciclastic sedimentary rocks & tuffaceous sedimentary rocks \\
\hline lacustrine sediments & | metamorphosed volcanic QAPF rocks & ultramafic rock \\
\hline lamprophyre & mixed carbonate/siliciclastic sedimentary rocks & volcanic QAPF rocks \\
\hline latite & mixed siliceous/phosphatic rocks & volcanic and unconsolidated rocks \\
\hline latitic-trachytic (alkaline) volcanic suite & mixed siliciclastic/carbonate sedimentary rocks & volcaniclastic and siliciclastic sedimentary rocks \\
\hline limestone & modern fluvial sediments (alluvium) & water body \\
\hline limestone conglomerate & monzogabbro & \\
\hline loess & monzogranite & \\
\hline
\end{tabular}

Figure 26-Continued. 


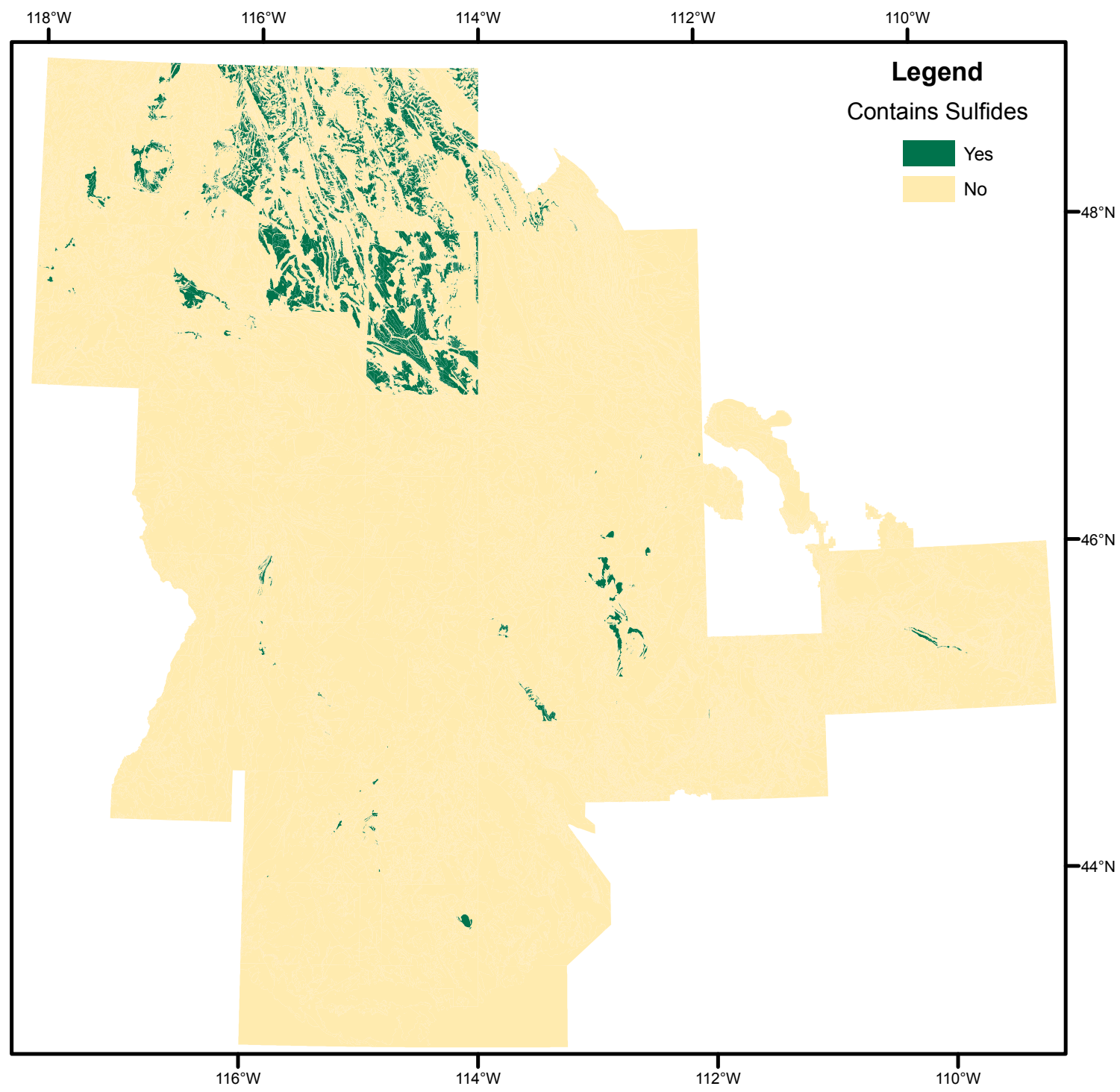

Figure 27. Geologic units in the northern Rocky Mountains described by source authors as containing sulfide minerals. 


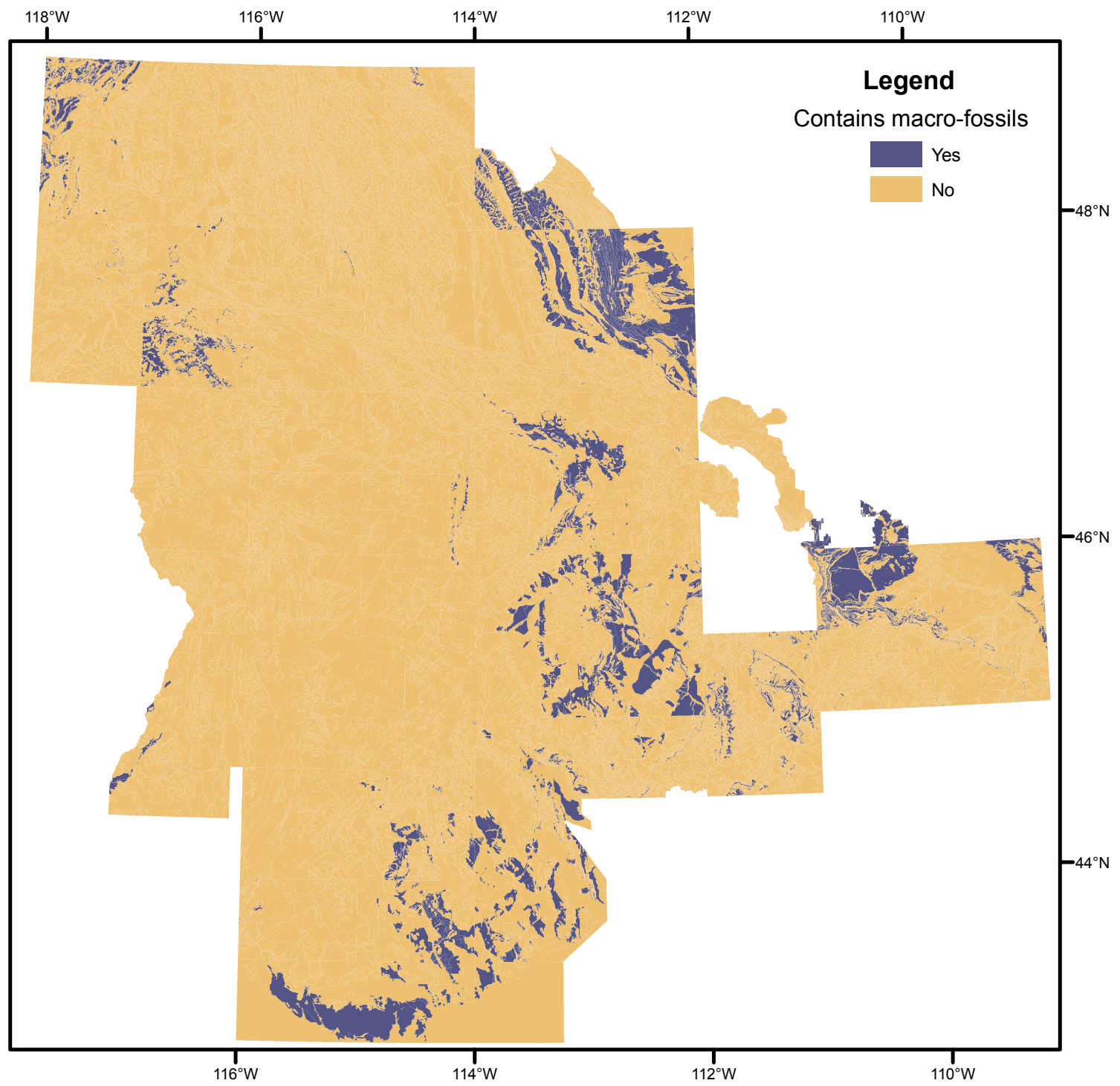

Figure 28. Geologic units in the northern Rocky Mountains described by source or secondary authors as containing fossils. 


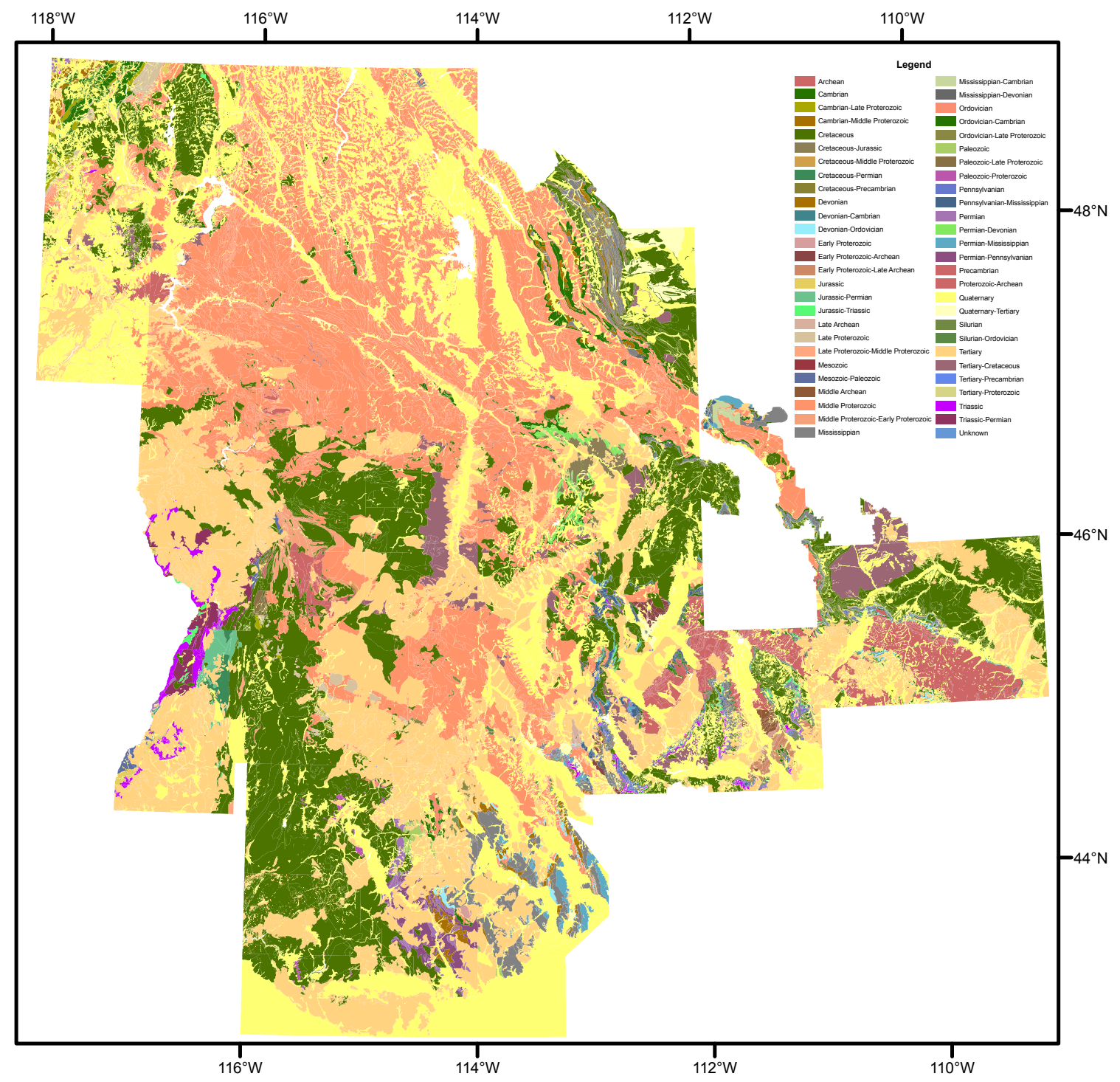

Figure 29. Stratigraphic-age map of the northern Rocky Mountains. 
Tables 1-19 

Table 1. List of objects (tables, queries, and forms) in the nrgeo.mdb database.

\begin{tabular}{|c|c|}
\hline \multicolumn{2}{|r|}{ Tables } \\
\hline Data table name & $\begin{array}{c}\text { Description } \\
\end{array}$ \\
\hline MUO & $\begin{array}{l}\text { Data table: Description of map units in the geologic map compilation of the } \\
\text { northern Rocky Mountains by Zientek and others (2005). }\end{array}$ \\
\hline NR_Bib & $\begin{array}{l}\text { Data table: Bibliography of geologic literature for the northern Rocky Moun- } \\
\text { tains of Idaho, Montana, and Washington. }\end{array}$ \\
\hline NR_Lith & $\begin{array}{l}\text { Data table: Lithologic (rock composition) information for geologic map } \\
\text { units. }\end{array}$ \\
\hline NR_Map_Title & Data table: Titles of source maps. \\
\hline NR_Rock_Comp & $\begin{array}{l}\text { Data table: Design based on Rock_Composition table in North American } \\
\text { Digital Geologic Data Model v. 4.3, Johnson and others, } 1999 \text {-- data } \\
\text { added by parsing the composition data from NR_Lith table into the } \\
\text { rock_name field. }\end{array}$ \\
\hline NR_Unit_Characteristic & Data table: Information about rock units based on selected properties. \\
\hline Stratigraphic_Age & Data table: Stratigraphic ages for rock units in northern Rocky Mountains. \\
\hline Look-up table name & Description \\
\hline Lith_Process_LU & $\begin{array}{l}\text { Look-up table: List of processes used to parse rock terms from source de- } \\
\text { scriptions into primary, secondary, and incidental categories in NR_Lith } \\
\text { table. [Processes are described by Zientek and others (2005, Appendix E).] }\end{array}$ \\
\hline NR_Eval_LU & $\begin{array}{l}\text { Look-up table: Definitions (names of coders) of initials used in Lith_eval } \\
\text { field of the NR_Lith table. }\end{array}$ \\
\hline NR_Lith_LU & $\begin{array}{l}\text { Look-up table: List of valid terms for attributing the dom_lith field of the } \\
\text { NR_Lith table. }\end{array}$ \\
\hline Strat_Age_LU & Look-up table: Age terms to use in Strat_name field in Stratigraphic_Age table. \\
\hline Strat_Rank_LU & Look-up table: Stratigraphic-rank terms and codes. \\
\hline Strat_Time_Scale_LU & $\begin{array}{l}\text { Look-up table: Master list of stratigraphic ages used in northern Rocky } \\
\text { Mountains geologic-map compilation. }\end{array}$ \\
\hline Unit_Type_LU & Look-up table: Codes used in unit_type field of MUO table. \\
\hline Join table name & $\begin{array}{c}\text { Description } \\
\end{array}$ \\
\hline MUO_Link & $\begin{array}{l}\text { Join table: MUO_Link table links } M U \_i d \text { values assigned to original source } \\
\text { map units to unique map units created for the regional map compilation by } \\
\text { Zientek and others (2005). }\end{array}$ \\
\hline MUO_Source_Link & $\begin{array}{l}\text { Join table: MUO_Source_Link table joins MUO table to NR_Bib table by } \\
\text { using a one-to-many-to-one relationship. }\end{array}$ \\
\hline Tree table name & $\begin{array}{c}\text { Description } \\
\end{array}$ \\
\hline NR_Lith_Tree & $\begin{array}{l}\text { Tree table: Hierarchical level within a lithologic classification system for } \\
\text { term listed in NR_Lith_LU table. }\end{array}$ \\
\hline Strat_Tree & Tree table: Stratigraphic Tree table of hierarchical relationship of age terms. \\
\hline \multicolumn{2}{|r|}{ Queries } \\
\hline Select queries & $\begin{array}{c}\text { Description } \\
\end{array}$ \\
\hline Lith_hierarchy_source_qry & $\begin{array}{l}\text { Select Query: Selects specific fields and data from NR_Lith, NR_Lith_LU, } \\
\text { and NR_Lith_Tree tables. Its output is used by Lith_hierarchy_source_ } \\
\text { crosstab_qry. }\end{array}$ \\
\hline NR_desc_pdf_qry & $\begin{array}{l}\text { Select Query: Selects map-unit descriptions (from } M U \_d e s c \text { field in the } \\
\text { MUO data table) as specified for use in the form NR_pdf_qry_frm. }\end{array}$ \\
\hline Strat_age_min_hierarchy_qry & $\begin{array}{l}\text { Select Query: Selects specific fields and data from Stratigraphic_Age, } \\
\text { Strat_Time_Scale_LU, and Strat_Tree tables. Its output is used by } \\
\text { Strat_age_min_hierarchy_crosstab_qry. }\end{array}$ \\
\hline Crosstab queries & $\begin{array}{c}\text { Description } \\
\end{array}$ \\
\hline Lith_hierarchy_source_crosstab_qry & $\begin{array}{l}\text { Crosstab Query: Provides hierarchical list of dominant lithologies for map } \\
\text { units; uses Lith_hierarchy_source_qry. }\end{array}$ \\
\hline Strat_age_min_hierarchy_crosstab_qry & $\begin{array}{l}\text { Crosstab Query: Provides hierarchical list of stratigraphic-age terms accord- } \\
\text { ing to the youngest age of the map units; uses Strat_age_min_hierar- } \\
\text { chy_qry. }\end{array}$ \\
\hline
\end{tabular}


Table 1. List of objects (tables, queries, and forms) in the nrgeo.mdb database.-Continued

\begin{tabular}{|c|c|}
\hline \multicolumn{2}{|r|}{ Tables } \\
\hline Data table name & Description \\
\hline Parameter queries & Description \\
\hline Age_hierarchy_parameter_qry & $\begin{array}{l}\text { Parameter Query (Interactive Select Query): Generalizes geologic age of map } \\
\text { unit to hierarchical rank specified by user when query is run. }\end{array}$ \\
\hline \multicolumn{2}{|r|}{ Forms } \\
\hline Startup, introductory, and main forms & Description \\
\hline 1-Startup_frm & Startup form: Provides user with preset choices of database operations. \\
\hline SplashScreen & $\begin{array}{l}\text { Form displays for } 5 \text { seconds when database opens, showing publication } \\
\text { credits. }\end{array}$ \\
\hline MUO_frm & Master data-entry form for MUO table (geologic map-unit objects). \\
\hline NR_pdf_qry_frm & $\begin{array}{l}\text { Form used to output description of map units and related information to an } \\
\text { Adobe PDF file published by Zientek and others (2005). }\end{array}$ \\
\hline Subforms & Description \\
\hline MUO_Link_Subfrm & $\begin{array}{l}\text { Subform used on MUO_frm showing link between original map units and } \\
\text { new units created for northern Rocky Mountains geologic-map compilation. }\end{array}$ \\
\hline NR_Bib_subfrm & $\begin{array}{l}\text { Subform used on MUO_frm for data input into NR_Bib table through the } \\
\text { source_id code }\end{array}$ \\
\hline NR_Lith_subfrm & Subform used on MUO_frm for data input into NR_Lith table. \\
\hline NR_pdf_Bib_subfrm & Subform used on NR_pdf_qry_frm to show references for each record. \\
\hline NR_Rock_Comp_subfrm & $\begin{array}{l}\text { Subform used on MUO_frm for data input into NR_Rock_Composition } \\
\text { table. }\end{array}$ \\
\hline NR_Unit_Characteristic_subfrm & $\begin{array}{l}\text { Subform used on MUO_frm for data input into NR_Unit_Characteristics } \\
\text { table. }\end{array}$ \\
\hline Stratigraphic_Age_subfrm & Subform used on MUO_frm for data input into Stratigraphic_Age table. \\
\hline
\end{tabular}


Table 2. MUO table design and summary.

\begin{tabular}{|c|c|c|c|}
\hline Table name & \multicolumn{3}{|c|}{ MUO } \\
\hline Format & \multicolumn{3}{|c|}{ Microsoft Access 2000 data table } \\
\hline Description & \multicolumn{3}{|c|}{$\begin{array}{l}\text { The table provides original geologic map- unit names and labels, new map-unit names and labels, } \\
\text { links to references and other data tables }\end{array}$} \\
\hline Keyfield & \multicolumn{3}{|c|}{$M U \_i d$} \\
\hline Relations & \multicolumn{3}{|c|}{$\begin{array}{l}M U \_i d \text { - 1-to-many relation to } M U \_i d \text { field in the Stratigraphic_Age, MUO_Link, MUO_Source_ } \\
\text { Link, and NR_Rock_Comp tables, and 1-to-1 relation to } M U \_i d \text { field in NR_Lith and NR_Unit_ } \\
\text { Characteristics tables; map_tile - many-to-1 to map_tile field in NR_Map_Tiles_LU; unit_type } \\
\text { - many-to-1 to } \text { unit_type field in Unit_Type_LU. }\end{array}$} \\
\hline Field name & Data type & Field size & Description \\
\hline$M U \_i d$ & Number & Long integer & $\begin{array}{l}\text { Unique integer for each map unit. Records with } M U \_i d>0 \text { and } \\
M U \_i d<4977 \text { represent original source-map (input) units; re- } \\
\text { cords with } M U \_i d>\text { or }=10000 \text { represent regional geologic-map } \\
\text { (output) units in the map compiled by Zientek and others }(2005) \text {. }\end{array}$ \\
\hline MU_lab_or & Text & 20 & $\begin{array}{l}\text { Map symbol, represented with ASCII characters, used to label } \\
\text { original or regional geologic-map units. }\end{array}$ \\
\hline MU_lab_gaf_or & Text & 20 & $\begin{array}{l}\text { Map symbol, represented with GeoAgeFullAlpha font-set charac- } \\
\text { ters, used to label original or regional geologic-map units. }\end{array}$ \\
\hline$M U \_n a m e \_o r$ & Text & 255 & Name of original or regional geologic- map unit. \\
\hline MU_type & Text & 50 & $\begin{array}{l}\text { Type of map-unit object (for example, rock unit, structure, meta- } \\
\text { morphic facies). }\end{array}$ \\
\hline MU_desc & Memo & NA & Description of geologic-map unit. \\
\hline source_id & Number & Long integer & $\begin{array}{l}\text { Integer used to identify source of original map-unit description. See } \\
\text { the table NR_Bib for complete references for the sources. }\end{array}$ \\
\hline map_tile & Text & 100 & $\begin{array}{l}\text { Name assigned to geologic map that was the principal source of in- } \\
\text { formation used in preparing the regional geologic-map compila- } \\
\text { tion (for } M U \_i d>0 \text { and } M U \_i d<4978 \text { ) OR Name of the geolog- } \\
\text { ic- map compilation (for } M U \_i d=10000 \text { or } M U \_i d>10000 \text { ). }\end{array}$ \\
\hline MU_name & Text & 255 & $\begin{array}{l}\text { Name assigned to regional geologic-map unit in the northern Rocky } \\
\text { Mountains geologic-map compilation by Zientek and others } \\
\text { (2005). }\end{array}$ \\
\hline$M U \_l a b$ & Text & 20 & $\begin{array}{l}\text { Map symbol, represented with ASCII characters, used to label } \\
\text { regional geologic-map units in the northern Rocky Mountains } \\
\text { geologic-map compilation by Zientek and others (2005). }\end{array}$ \\
\hline$M U \_l a b \_g a f$ & Text & 20 & $\begin{array}{l}\text { Map symbol, represented with GeoAgeFullAlpha font-set charac- } \\
\text { ters, used to label regional geologic-map units in the northern } \\
\text { Rocky Mountains geologic map compilation by Zientek and } \\
\text { others (2005). }\end{array}$ \\
\hline unit_type & Text & 2 & $\begin{array}{l}\text { Designator indicating type of stratigraphic unit: } \mathrm{F}=\text { formal strati- } \\
\text { graphic unit, } \mathrm{IF}=\text { informal member of formal stratigraphic unit, I } \\
\text { = informal unit, } \mathrm{U}=\text { unconsolidated material. }\end{array}$ \\
\hline
\end{tabular}


Table 3. NR_Bib table design and summary.

\begin{tabular}{|c|c|c|c|}
\hline Table name & \multicolumn{3}{|c|}{ NR_Bib } \\
\hline Format & \multicolumn{3}{|c|}{ Microsoft Access 2000 data table } \\
\hline Description & \multicolumn{3}{|c|}{ The table provides reference information for the units. } \\
\hline Keyfield & \multicolumn{3}{|c|}{ source_id } \\
\hline Relations & \multicolumn{3}{|c|}{ 1-to-many relation to source_id field in MUO_Source_Link table } \\
\hline Field name & Data type & \begin{tabular}{|l|} 
Field size \\
\end{tabular} & \begin{tabular}{|r|} 
Description \\
\end{tabular} \\
\hline source_id & Number & Long integer & Unique source identification number. \\
\hline cited & Text & 1 & $\begin{array}{l}\text { X - Indicates that data source was cited by Zientek and others (2005); no } \\
\text { entry indicates that source was not cited by Zientek and others (2005). }\end{array}$ \\
\hline originator & Text & 255 & Name(s) of author(s) or compiler(s) of data source. \\
\hline date & Text & 255 & $\begin{array}{l}\text { Date of data-source publication, OR date that data were made available } \\
\text { for our use, OR comments regarding publication status or how data was } \\
\text { acquired. Year in brackets indicates publication-release date if different } \\
\text { from publication date. }\end{array}$ \\
\hline version & Text & 255 & Version of the publication. \\
\hline title & Memo & & Complete title of the data source. \\
\hline lw1_author & Text & 255 & $\begin{array}{l}\text { Name of author(s) or compiler(s) of the first larger work when cited publi- } \\
\text { cation is within a larger publication. }\end{array}$ \\
\hline lw1_title & Text & 255 & Title of the first larger work. \\
\hline lw2_author & Text & 255 & $\begin{array}{l}\text { Name of the author(s) or compiler(s) of the second larger work when } \\
\text { larger work is within another publication. }\end{array}$ \\
\hline lw2_title & Text & 255 & Title of the second larger work. \\
\hline pub & Text & 255 & $\begin{array}{l}\text { Publisher, publication series and number (or other designation), and } \\
\text { remainder of reference in U.S. Geological Survey reference style for } \\
\text { published data. }\end{array}$ \\
\hline scale_pub & Number & Long integer & $\begin{array}{l}\text { Source scale (given as the denominator of the proportional fraction) of the } \\
\text { published geologic map. }\end{array}$ \\
\hline scale_base & Number & Long integer & $\begin{array}{l}\text { Source scale (given as the denominator of the proportional fraction) of the } \\
\text { original base map on which the geology was mapped or compiled. }\end{array}$ \\
\hline$U R L$ & Text & 255 & $\begin{array}{l}\text { Uniform Resource Locator; an address that specifies the location of a file } \\
\text { on the Internet. }\end{array}$ \\
\hline citation & Memo & & Full citation for data source in U.S. Geological Survey reference style. \\
\hline text_citation & Text & 100 & $\begin{array}{l}\text { Abbreviation of citation for use when data source is cited within the body } \\
\text { of a report. }\end{array}$ \\
\hline
\end{tabular}


Table 4. NR_Lith table design and summary.

\begin{tabular}{|c|c|c|c|}
\hline Table name & \multicolumn{3}{|c|}{ NR_Lith } \\
\hline Format & \multicolumn{3}{|c|}{ Microsoft Access 2000 data table } \\
\hline Description & \multicolumn{3}{|c|}{ The table provides description of the lithology of the unit. } \\
\hline Keyfield & \multicolumn{3}{|c|}{$M U \_i d$} \\
\hline Relations & \multicolumn{3}{|c|}{$\begin{array}{l}\text { MU_id - 1-1 relation to } M U \_i d \text { field of } \mathbf{M U O} \text { table; dom_lith - many-to-1 relation to lith_name in } \\
\text { NR_Lith_LU; lith_process - many-to-1 relation to lith_process in Lith_Process_LU. }\end{array}$} \\
\hline Field name & Data type & Field size & Description \\
\hline MU_id & Number & Long integer & Unique identifier for map unit. \\
\hline dom_lith & Text & 100 & $\begin{array}{l}\text { Dominant rock or rock material present in the geologic entity that } \\
\text { is represented by a map unit. Attributes were selected from the } \\
\text { Lith_name field of the NR_Lith_LU table. No data means that } \\
\text { the evaluator was unable to determine a rock type from the source } \\
\text { material descriptions. [The dom_lith field corresponds to the } \\
\text { lname_dom and uname_dom fields in NR_GEO.LITH and NR_- } \\
\text { GEOL.UN tables, respectively, of Zientek and others (2005).] }\end{array}$ \\
\hline primary_lith & Memo & & $\begin{array}{l}\text { Primary rock or rock-material terms describing map units, as re- } \\
\text { ported in source publications. Sometimes modified by secondary } \\
\text { sources if primary-source description was deficient. (The field } \\
\text { corresponds to name_majrl and name_majr2 fields in NR_GEO. } \\
\text { LITH table and name_major field in NR_GEOLUN table of } \\
\text { Zientek and others (2005).) }\end{array}$ \\
\hline subordinate_lith & Text & 255 & $\begin{array}{l}\text { Minor rock or rock-material terms describing map units, as reported } \\
\text { in source publications. [The field corresponds to name_minor } \\
\text { field in NR_GEO.LITH and NR_GEOL.UN tables of Zientek } \\
\text { and others (2005).] }\end{array}$ \\
\hline incidental_lith & Text & 255 & $\begin{array}{l}\text { Incidental rock or rock-material terms describing map units, as } \\
\text { reported in source publications. [The field corresponds to name_- } \\
\text { other field in NR_GEO.LITH and NR_GEOL.UN tables of } \\
\text { Zientek and others (2005).] }\end{array}$ \\
\hline lith_eval & Text & 100 & $\begin{array}{l}\text { Initials of person(s) responsible for interpreting and entering litho- } \\
\text { logic data into the table or proofing the table. (Evaluators' names } \\
\text { are listed in the NR_Eval_LU look-up table.) }\end{array}$ \\
\hline unit_form & Text & 50 & Geologic or geomorphic form of the mapped geologic unit. \\
\hline lith_comment & Memo & & Comments from evaluator(s). \\
\hline econ_geol & Yes/No & & $\begin{array}{l}\text { Notation indicating an economic geology component in the map- } \\
\text { unit description: Yes = economic component present, No = } \\
\text { economic component is not present. }\end{array}$ \\
\hline lith_process & Text & 50 & $\begin{array}{l}\text { Parsing rule used to extract data to the primary_lith, subordinate } \\
\text { lith, and incidental_lith fields. }\end{array}$ \\
\hline
\end{tabular}

Table 5. NR_Map_Title table design and summary.

\begin{tabular}{|l|l|l|l|}
\hline Table name & NR_Map_Title \\
\hline Format & Microsoft Access 2000 data table \\
\hline Description & The table provides a full and abbreviated name for maps that were the source of data. \\
\hline Keyfield & map_tile \\
\hline Relations & 1-to-many relation to map_tile field in MUO table \\
\hline \multicolumn{1}{|c|}{ Field name } & Data type & Field size & \multicolumn{1}{c|}{ Description } \\
\hline map_tile & Text & 100 & $\begin{array}{c}\text { Name for the map that is the principal source of information. The } \\
\text { name is coined by combining an abbreviation of a topographic } \\
\text { map or National Forest name and the published map scale. }\end{array}$ \\
\hline title & Text & 255 & Title on geologic map that was source of the geologic mapping. \\
\hline spatial_DB_name & Text & 100 & $\begin{array}{c}\text { Name of geology spatial database used to make northern Rocky } \\
\text { Mountain GIS (nrgeo) in Zientek and others (2005). }\end{array}$ \\
\hline
\end{tabular}


Table 6. NR_Rock_Comp table design and summary.

\begin{tabular}{|c|c|c|c|}
\hline Table name & \multicolumn{3}{|c|}{ NR_Rock_Comp } \\
\hline Format & \multicolumn{3}{|c|}{ Microsoft Access 2000 data table } \\
\hline Description & \multicolumn{3}{|c|}{ The table provides information on characteristics of rocks within the unit. } \\
\hline Keyfield & \multicolumn{3}{|c|}{ MU_id,comp_seq, lith_rank } \\
\hline Relations & \multicolumn{3}{|c|}{ Many-to-1 relation of $M U \_i d$ field to $M U \_i d$ field in MUO table } \\
\hline Field name & Data type & Field size & \begin{tabular}{|c|} 
Description \\
\end{tabular} \\
\hline$M U \_i d$ & Number & Long integer & $\begin{array}{l}\text { Map- unit identification number for map unit-linking field to } \\
\text { MUO table. }\end{array}$ \\
\hline comp_seq & Number & Long integer & $\begin{array}{l}\text { Unique identification number of a composition within a rock } \\
\text { unit. Also indicates sequence number for displaying descrip- } \\
\text { tive information about this composition within a rock-unit } \\
\text { description. This order is based on an assumption that the } \\
\text { authors of the source publications sequenced from most to } \\
\text { least abundant lithology in their descriptions. }\end{array}$ \\
\hline rock_name & Text & 255 & $\begin{array}{l}\text { A free-text attribute for storing the map author's preferred com- } \\
\text { plete name for the rock composition. }\end{array}$ \\
\hline lith_class & Text & 255 & A lithologic classification term. \\
\hline lith_rank & & Integer & $\begin{array}{l}\text { Rank is a numeric value indicating importance, with } 1 \text { mean- } \\
\text { ing most important rock type to } 3 \text { meaning rarely present } \\
\text { rock type. Coding based on presence in primary_lith (1), } \\
\text { subordinate_lith (2), or incidental_lith (3) fields of NR_Lith } \\
\text { table. There may be more than one rock type with the same } \\
\text { lith_rank number. }\end{array}$ \\
\hline lith_form & Text & 50 & A form or morphology-classification term. \\
\hline vol_percent & Number & Integer & $\begin{array}{l}\text { An estimate of the volume-percent of the composition within the } \\
\text { rock unit. }\end{array}$ \\
\hline vol_quality & Number & Integer & $\begin{array}{l}\text { Quality of the volume percent estimate (entered as a percent } \\
\text { number between } 0 \text { and } 100 \text { ). }\end{array}$ \\
\hline mineralogy_desc & Text & 255 & $\begin{array}{l}\text { A mineral modifier associated with the rock name, or descrip- } \\
\text { tion of the mineralogy of the composition. }\end{array}$ \\
\hline color_desc & Text & 255 & A description of the color or colors of the composition. \\
\hline texture_desc & Text & 255 & A description of the texture of the composition. \\
\hline grain_size & Text & 50 & A description of grain size. \\
\hline grain_size_variation & Text & 50 & A description of the variation in grain size. \\
\hline grain_size_grdmass & Text & 50 & Grain size of the groundmass. \\
\hline alteration_desc & Text & 255 & A description of any alteration associated with the composition. \\
\hline data_quality & Number & Integer & $\begin{array}{l}\text { Quality of the description of the rock. Value from } 1 \text { to } 10 \text {, where } \\
10 \text { is best. }\end{array}$ \\
\hline description & Memo & & A text description of this composition. \\
\hline
\end{tabular}


Table 7. NR_Unit_Characteristic table design and summary.

\begin{tabular}{|c|c|c|c|}
\hline Table name & \multicolumn{3}{|c|}{ NR_Unit_Characteristics } \\
\hline Format & \multicolumn{3}{|c|}{ Microsoft Access 2000 data table } \\
\hline Description & \multicolumn{3}{|c|}{ The table provides information on chemical characteristics, fossils, and organic matter of the unit. } \\
\hline Keyfield & \multicolumn{3}{|c|}{$M U \_i d$} \\
\hline Relations & \multicolumn{3}{|c|}{ 1-to-1 relation to $\boldsymbol{M U} \boldsymbol{i} \boldsymbol{i d}$ field in MUO table } \\
\hline Field name & Data type & Field size & Description \\
\hline$M U \_i d$ & Number & Long integer & $\begin{array}{l}\text { Map unit identification number for map unit-linking field to MUO } \\
\text { table. }\end{array}$ \\
\hline organic & Text & 3 & $\begin{array}{l}\text { Yes indicates organic material present in map unit. No means no } \\
\text { description of organic material is provided in source descrip- } \\
\text { tion. }\end{array}$ \\
\hline sufidic & Text & 3 & $\begin{array}{l}\text { Yes indicates sulfur present in map unit. No means no description } \\
\text { of sulfur-bearing material is provided in source description. }\end{array}$ \\
\hline carbonate & Text & 3 & $\begin{array}{l}\text { Yes indicates carbonate minerals present in map unit. No means } \\
\text { no description of carbonate material is provided in source } \\
\text { description. }\end{array}$ \\
\hline fossiliferous & Text & 3 & $\begin{array}{l}\text { Yes indicates macro-fossils present in map unit (Stromatolites } \\
\text { not included). No means no macro-fossils are described in source } \\
\text { publication. }\end{array}$ \\
\hline oscf_desc & Memo & & $\begin{array}{l}\text { Explanation for the "Yes" selection for organic, sulfidic, car- } \\
\text { bonate, or fossiliferous fields. }\end{array}$ \\
\hline
\end{tabular}

Table 8. Stratigraphic_Age table design and summary.

\begin{tabular}{|c|c|c|c|}
\hline Table name & \multicolumn{3}{|c|}{ Stratigraphic_Age } \\
\hline Format & \multicolumn{3}{|c|}{ Microsoft Access 2000 data table } \\
\hline Description & \multicolumn{3}{|c|}{ The table provides information on the stratigraphic age of each unit. } \\
\hline Keyfields & \multicolumn{3}{|c|}{$M U \_i d$, strat_seq } \\
\hline Relations & \multicolumn{3}{|c|}{$\begin{array}{l}M U \_i d \text { - many-to-1 relation to } M U \_i d \text { field in MUO table, strat_name relates to strat_name in } \\
\text { Strat_Age_LU table, } m i n \_s t r a t \_n a m e \text { and } m a x \_s t r a t \_n a m e \text { relate to } m i n \_m a x \_s t r a t \_n a m e \text { in } \\
\text { Strat_Age_LU table }\end{array}$} \\
\hline Field name & Data type & Field size & \begin{tabular}{|c|} 
Description \\
\end{tabular} \\
\hline$M U \_i d$ & Number & Long integer & $\begin{array}{l}\text { Map unit identification number for map unit-linking field to MUO } \\
\text { table. }\end{array}$ \\
\hline strat_seq & Double & & $\begin{array}{l}\text { Record identifier for a specific time interval for the unit identified } \\
\text { by the } M U \_i d \text {. For maps from Idaho Geological Survey, IGS } \\
\text { numbers are used. }\end{array}$ \\
\hline min_strat_name & Text & 50 & $\begin{array}{l}\text { The minimum time-stratigraphic age selected from the Stratigraphic } \\
\text { Time Scale table. }\end{array}$ \\
\hline max_strat_name & Text & 50 & $\begin{array}{l}\text { The maximum time-stratigraphic age selected from the Stratigraphic } \\
\text { Time Scale table. }\end{array}$ \\
\hline strat_name & Text & 50 & $\begin{array}{l}\text { Stratigraphic-age term for geologic-period level (or hierarchically } \\
\text { above period if necessary). Contains combined-age terms when } \\
\text { minimum and maximum ages differ. }\end{array}$ \\
\hline min_source_id & Number & Long integer & $\begin{array}{l}\text { Unique identification number of an information source for the } \\
\text { minimum-age reference from the source table. }\end{array}$ \\
\hline max_source_id & Number & Long integer & $\begin{array}{l}\text { Unique identification number of an information source for the } \\
\text { maximum-age reference from the source table }\end{array}$ \\
\hline
\end{tabular}


Table 9. NR_Eval_LU table design and summary.

\begin{tabular}{|c|c|c|c|}
\hline Table name & \multicolumn{3}{|c|}{ NR_Eval_LU } \\
\hline Format & \multicolumn{3}{|c|}{ Microsoft Access 2000 look-up table } \\
\hline Description & \multicolumn{3}{|c|}{ The table provides the full name of the evaluators in the lith_eval field in the NR_Lith table. } \\
\hline Keyfield & \multicolumn{3}{|c|}{ lith_eval } \\
\hline Relations & \multicolumn{3}{|c|}{ None, used to check correct use of initials in lith_eval field of NR_Lith table } \\
\hline Field name & Data type & Field size & \begin{tabular}{|c|} 
Description \\
\end{tabular} \\
\hline lith_eval & Text & 5 & Initials of the person who evaluated and coded lithologic data. \\
\hline lith_eval_name & Text & 50 & Name of the person who evaluated and coded lithologic data. \\
\hline
\end{tabular}

Table 10. NR_Lith_LU table design and summary.

\begin{tabular}{|c|c|c|c|}
\hline Table name & \multicolumn{3}{|l|}{ NR_Lith_LU } \\
\hline Format & \multicolumn{3}{|c|}{ Microsoft Access 2000 look-up table } \\
\hline Description & \multicolumn{3}{|c|}{$\begin{array}{l}\text { The table provides a valid list of terms for the dom_lith field in the NR_Lith table and a hierarchy } \\
\text { for those terms. }\end{array}$} \\
\hline Keyfield & \multicolumn{3}{|c|}{ lith_name } \\
\hline Relations & \multicolumn{3}{|c|}{ 1-to-many relation to dom_lith field in NR_Lith table } \\
\hline Field name & Data type & Field size & Description \\
\hline lith_name & Text & 100 & $\begin{array}{l}\text { Name describing lithologic character of rock unit (from a hierarchi- } \\
\text { cal classification of lithology terms compiled for the nrgeo.mdb } \\
\text { database). }\end{array}$ \\
\hline lith_id & Number & Long integer & $\begin{array}{l}\text { Unique identification number for lithologic term. Links to the NR_- } \\
\text { Lith_Tree table to identify parent-child relations in a hierarchi- } \\
\text { cal classification system. }\end{array}$ \\
\hline lith_level & Number & Integer & $\begin{array}{l}\text { A numeric value for the level in a hierarchical classification of } \\
\text { lithologic terms. }\end{array}$ \\
\hline lith_defn & Memo & & Geologic definition of the lithologic term. \\
\hline defn_type & Text & 10 & $\begin{array}{l}\text { Type of material being defined: rock, water, or unit (where type of } \\
\text { material is either unconsolidated material or a group/mixture/suite } \\
\text { of rock types). }\end{array}$ \\
\hline lith_ref & Text & 255 & Abbreviated citation for source of term used in Lith_name field. \\
\hline source_id & Number & Long integer & $\begin{array}{l}\text { Unique identification number for publication cited in lith_ref field. } \\
\text { Links to source_id field in NR_Bib table. }\end{array}$ \\
\hline
\end{tabular}

Table 11. Strat_Age_LU table design and summary.

\begin{tabular}{|c|c|c|c|}
\hline Table name & \multicolumn{3}{|c|}{ Strat_Age_LU } \\
\hline Format & \multicolumn{3}{|c|}{ Microsoft Access 2000 look-up table } \\
\hline Description & \multicolumn{3}{|c|}{ The table provides a list of valid terms for the strat_name field in the Stratigraphic_Age table. } \\
\hline Keyfield & \multicolumn{3}{|c|}{ strat_age_id } \\
\hline Relations & \multicolumn{3}{|c|}{$\begin{array}{l}\text { 1-to-many relation min_max_strat_name to min_strat_name and max_strat_name field and } \\
\text { strat_name to } \text { strat name in Stratigraphic_Age table }\end{array}$} \\
\hline Field name & Data type & Field size & Description \\
\hline strat_age_id & Number & Long integer & Unique identification number for a stratigraphic-age term. \\
\hline min_max_strat_name & Text & 50 & Unique list of combined minimum-maximum-age terms. \\
\hline strat_name & Text & 50 & $\begin{array}{l}\text { List of combined minimum-maximum-age terms at geologic- } \\
\text { period level for Phanerozoic and era level for Precambrian } \\
\text { when possible. }\end{array}$ \\
\hline min_strat_age & Number & Double & Minimum numerical age, in millions of years. \\
\hline max_strat_age & Number & Double & Maximum numerical age, in millions of years. \\
\hline
\end{tabular}


Table 12. Strat_Rank_LU table design and summary.

\begin{tabular}{|c|c|c|c|}
\hline Table name & \multicolumn{3}{|c|}{ Strat_Rank_LU } \\
\hline Format & \multicolumn{3}{|c|}{ Microsoft Access 2000 look-up table } \\
\hline Description & \multicolumn{3}{|c|}{ The table provides a way to order stratigraphic age terms according to hierarchical ranking. } \\
\hline Keyfield & \multicolumn{3}{|c|}{ strat_rank } \\
\hline Relations & \multicolumn{3}{|c|}{ 1-to-many relation to strat_rank field of Strat_Time_Scale_LU table } \\
\hline Field name & \begin{tabular}{|l|} 
Data type \\
\end{tabular} & Field size & Description \\
\hline strat_rank & Text & 50 & A keyword representing the rank of the time-stratigraphic term. \\
\hline strat_level & Number & Long integer & A numeric value for the level in the hierarchy of time-stratigraphic terms. \\
\hline
\end{tabular}

Table 13. Strat_Time_Scale LU table design and summary.

\begin{tabular}{|l|l|l|l|}
\hline Table name & \multicolumn{2}{|l|}{ Strat_Time_Scale_LU } \\
\hline Format & \multicolumn{2}{l|}{$\begin{array}{l}\text { Microsoft Access 2000 look-up table } \\
\text { Description }\end{array}$} & $\begin{array}{l}\text { The table provides a list of valid terms for the min_strat_age } \text { and max_strat_age fields in the Strati- } \\
\text { graphic_Age table. }\end{array}$ \\
\hline Keyfield & strat_id \\
\hline Relations & 1-to-many relation to strat_id field in Strat_Tree table \\
\hline \multicolumn{1}{|c|}{ Field name } & \multicolumn{1}{|c|}{ Data type } & Field size & \multicolumn{1}{c|}{ Description } \\
\hline strat_id & Number & Long integer & A unique identifier for the strat_name. \\
\hline strat_name & Text & 255 & The time-stratigraphic name for the time interval. \\
\hline strat_rank & Text & 10 & $\begin{array}{c}\text { A keyword representing the rank of the time-stratigraphic term. } \\
\text { Must be included in the Strat_Rank_LU table. }\end{array}$ \\
\hline min_strat_age & Number & Double & Minimum numerical age, in millions of years. \\
\hline max_strat_age & Number & Double & Maximum numerical age, in millions of years. \\
\hline min_source_id & Number & Long integer & $\begin{array}{c}\text { Unique identification number of an information source for the } \\
\text { minimum-age reference. }\end{array}$ \\
\hline max_source_id & Number & Long integer & $\begin{array}{l}\text { Unique identification number of an information source for the } \\
\text { maximum-age reference. }\end{array}$ \\
\hline
\end{tabular}

Table 14. Lith_Process_LU table design and summary.

\begin{tabular}{|c|c|c|c|}
\hline Table name & \multicolumn{3}{|c|}{ Lith_Process_LU } \\
\hline Format & \multicolumn{3}{|c|}{ Microsoft Access 2000 look-up table } \\
\hline Description & \multicolumn{3}{|c|}{ The table provides a list of valid terms for the lith_process field in the NR_Lith table. } \\
\hline Keyfield & \multicolumn{3}{|c|}{ lith_process } \\
\hline Relations & \multicolumn{3}{|c|}{ 1-to- many relation to lith_process field of NR_Lith table } \\
\hline Field name & Data type & Field size & Description \\
\hline lith_process & Text & 50 & $\begin{array}{l}\text { Term describing the process used to parse rock terms into categories that } \\
\text { infer the importance of those rocks within a map unit. }\end{array}$ \\
\hline lith_process_desc & Memo & & $\begin{array}{l}\text { Description of the process to interpret and convert an author's map-unit de- } \\
\text { scription into a three-level ranking system of importance of a rock type } \\
\text { within a map unit. Description taken from Zientek and others (2005). }\end{array}$ \\
\hline
\end{tabular}

Table 15. Unit_Type_LU table design and summary.

\begin{tabular}{|c|c|c|c|}
\hline Table name & \multicolumn{3}{|c|}{ Unit_Type_LU } \\
\hline Format & \multicolumn{3}{|c|}{ Microsoft Access 2000 look-up table } \\
\hline Description & \multicolumn{3}{|c|}{ The table provides a list of valid terms for the unit_type field in the MUO table. } \\
\hline Keyfield & \multicolumn{3}{|c|}{ unit_type } \\
\hline Relations & \multicolumn{3}{|c|}{ 1-to-many relation to Unit_type field in MUO table } \\
\hline Field name & \begin{tabular}{|l|} 
Data type \\
\end{tabular} & Field size & Description \\
\hline unit_type & Text & 2 & Abbreviation for categorization of geologic-unit name. \\
\hline unit_type_desc & Text & 50 & $\begin{array}{l}\text { Descriptive name for unit_type field: Formal unit, informal part of formal } \\
\text { unit, informal unit, unconsolidated unit. }\end{array}$ \\
\hline definition & Text & 255 & Definition of unit_type_desc term. \\
\hline
\end{tabular}


Table 16. MUO_link table design and summary.

\begin{tabular}{|c|c|c|c|}
\hline Table name & \multicolumn{3}{|l|}{ MUO_link } \\
\hline Format & \multicolumn{3}{|c|}{ Microsoft Access 2000 join table } \\
\hline Description & \multicolumn{3}{|c|}{ The table provides a link between map units used in different publications. } \\
\hline Keyfield & \multicolumn{3}{|c|}{$M U \_i d, C G \_M U \_i d$} \\
\hline Relations & \multicolumn{3}{|c|}{$M U \_i d$ and $C G \_M U \_i d$ many-to-1 relation to $M U \_i d$ field in $\mathbf{M U O}$ table } \\
\hline Field name & Data type & Field size & \begin{tabular}{|r|} 
Description \\
\end{tabular} \\
\hline$M U \_i d$ & Number & Long integer & $\begin{array}{l}\text { Unique integer for map unit. Records with } M U \_i d>0 \text { and }<4,977 \\
\text { represent original source-map (input) units; records with } M U \_i d> \\
\text { = } 10,000 \text { represent regional geologic-map (output) units in the map } \\
\text { compilation by Zientek and others (2005). }\end{array}$ \\
\hline$C G \_M U \_i d$ & Number & Long integer & Unique intermediate identifier for regional geologic-map (output) unit. \\
\hline
\end{tabular}

Table 17. MUO_Source_Link table design and summary.

\begin{tabular}{|c|c|c|c|}
\hline Table name & \multicolumn{3}{|c|}{ MUO_Source_Link } \\
\hline Format & \multicolumn{3}{|c|}{ Microsoft Access 2000 join table } \\
\hline Description & \multicolumn{3}{|c|}{ The table provides link between map units and bibliographic references } \\
\hline Keyfield & \multicolumn{3}{|c|}{ MU_id, source_id } \\
\hline Relations & \multicolumn{3}{|c|}{$\begin{array}{l}M U \_i d \text { many-to-1 relation to } M U \_i d \text { in } \mathbf{M U O} \text { table, source_id many-to-1 relation to source_id in } \\
\text { NR_Bib table }\end{array}$} \\
\hline Field name & Data type & Field size & \begin{tabular}{|c|} 
Description \\
\end{tabular} \\
\hline$M U \_i d$ & Number & Long integer & Unique integer for map unit. \\
\hline source_id & Number & Long integer & $\begin{array}{l}\text { Integer used to identify source of original map-unit description. See the } \\
\text { NR_Bib table for complete references for the sources. }\end{array}$ \\
\hline
\end{tabular}

Table 18. NR_Lith_Tree table design and summary.

\begin{tabular}{|c|c|c|c|}
\hline Table name & \multicolumn{3}{|c|}{ NR_Lith_Tree } \\
\hline Format & \multicolumn{3}{|c|}{ Microsoft Access 2000 tree table } \\
\hline Description & \multicolumn{3}{|c|}{ The table provides links to between hierarchically related lithologic terms for each map unit. } \\
\hline Keyfield & \multicolumn{3}{|c|}{ parent_lith_id, lith_id } \\
\hline Relations & \multicolumn{3}{|c|}{ parent_lith_id and lith_id many-to-1 relation to lith_id in NR_Lith_LU table } \\
\hline Field name & Data type & Field size & Description \\
\hline parent_lith_id & Number & Long integer & Lithology identification number of the parent lithology term to lith_id. \\
\hline lith_id & Number & Long integer & Identification number for a lithology term in the $\mathbf{N R} \_\mathbf{L i t h} \_\mathbf{L U}$ table. \\
\hline
\end{tabular}

Table 19. Strat_Tree table design and summary.

\begin{tabular}{|c|c|c|c|}
\hline Table name & \multicolumn{3}{|l|}{ Strat_Tree } \\
\hline Format & \multicolumn{3}{|c|}{ Microsoft Access 2000 tree table } \\
\hline Description & \multicolumn{3}{|c|}{ The table provides links to hierarchically related terms for stratigraphic ages for each map unit. } \\
\hline Keyfield & \multicolumn{3}{|c|}{ strat_id,parent_strat_id } \\
\hline Relations & \multicolumn{3}{|c|}{ Many-to-1 relation between strat_id and strat_id field of Strat_Time_Scale_LU table. } \\
\hline Field name & Data type & Field size & Description \\
\hline strat_id & Number & Long integer & $\begin{array}{l}\text { An identification number for a time-stratigraphic interval from the } \\
\text { Stratigraphic_Time_Scale_LU table. }\end{array}$ \\
\hline parent_strat_id & Number & Long integer & $\begin{array}{l}\text { An identification number for a second time-stratigraphic interval from } \\
\text { the Stratigraphic_Time_Scale_LU table, which is a parent of the } \\
\text { first interval. }\end{array}$ \\
\hline
\end{tabular}


Inside Back Cover

This page left blank intentionally. 


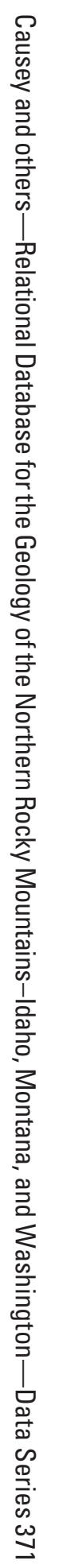

